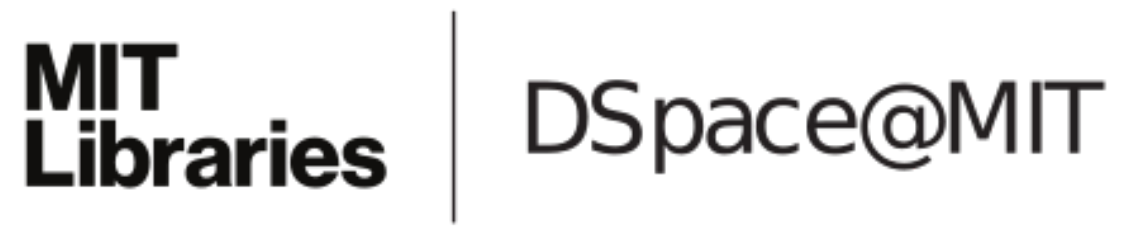

\author{
MIT Open Access Articles
}

P-N Cooperative Borane Activation and Catalytic Hydroboration by a Distorted Phosphorous Triamide Platform

The MIT Faculty has made this article openly available. Please share how this access benefits you. Your story matters.

Citation: Lin, Yi-Chun et al. “P-N Cooperative Borane Activation and Catalytic Hydroboration by a Distorted Phosphorous Triamide Platform." Journal of the American Chemical Society 139, 16 (April 2017): 6008-6016 (c) 2017 American Chemical Society

As Published: http://dx.doi.org/10.1021/jacs.7b02512

Publisher: American Chemical Society (ACS)

Persistent URL: http://hdl.handle.net/1721.1/114818

Version: Author's final manuscript: final author's manuscript post peer review, without publisher's formatting or copy editing

Terms of Use: Article is made available in accordance with the publisher's policy and may be subject to US copyright law. Please refer to the publisher's site for terms of use. 
Published in final edited form as:

J Am Chem Soc. 2017 April 26; 139(16): 6008-6016. doi:10.1021/jacs.7b02512.

\title{
P-N Cooperative Borane Activation and Catalytic Hydroboration by a Distorted Phosphorous Triamide Platform
}

\author{
Yi-Chun Lin ${ }^{\dagger}$, Emmanuel Hatzakis ${ }^{\ddagger}$, Sean M. McCarthy§, Kyle D. Reichl§, Ting-Yi Lai§, \\ Hemant P. Yennawar§," , and Alexander T. Radosevich ${ }^{\dagger,}{ }^{*}$ \\ tDepartment of Chemistry, Massachusetts Institute of Technology, Cambridge, MA 02139 \\ ‡Department of Food Science and Technology, The Ohio State University, Columbus, $\mathrm{OH} 43210$ \\ §Department of Chemistry, The Pennsylvania State University, University Park, PA 16802 \\ "X-Ray Crystallography Laboratory, Department of Biochemistry and Molecular Biology, The \\ Pennsylvania State University, University Park, PA 16802
}

\begin{abstract}
Studies on the stoichiometric and catalytic reactivity of a geometrically constrained phosphorous triamide 1 with pinacolborane (HBpin) are reported. The addition of HBpin to phosphorous triamide 1 results in cleavage of the B-H bond of pinacolborane through addition across electrophilic phosphorus and nucleophilic $N$-methylanilide sites in a cooperative fashion. The kinetics of this process of were investigated by NMR spectroscopy, with the determined overall second order empirical rate law given by $v=-k[1][\mathrm{HB} p i n]$ where $k=4.76 \times 10^{-5} \mathrm{M}^{-1} \mathrm{~s}^{-1}$ at $25^{\circ} \mathrm{C}$. The B-H bond activation process produces a $P$-hydrido-1,3,2-diazaphospholene intermediate 2 , which exhibits hydridic reactivity capable of reacting with imines to give phosphorous triamide intermediates, as confirmed by independent synthesis. These phosphorous triamide intermediates are typically short-lived, evolving with elimination of the $\mathrm{N}$-borylamine product of imine hydroboration with regeneration of the deformed phosphorous triamide $\mathbf{1}$. The kinetics of this latter process are shown to be first-order, indicative of a unimolecular mechanism. Consequently, catalytic hydroboration of a variety of imine substrates can be realized with $\mathbf{1}$ as catalyst and HBpin as terminal reagent. A mechanistic proposal implicating a $\mathrm{P}-\mathrm{N}$ cooperative mechanism for catalysis that incorporates the various independently verified stoichiometric steps is presented and a comparison to related phosphorus-based systems is offered.
\end{abstract}

\section{TOC GRAPHIC}

*Corresponding Author. radosevich@mit.edu. ASSOCIATED CONTENT

Supporting Information. Full experimental procedures; ${ }^{1} \mathrm{H},{ }^{13} \mathrm{C}$, and ${ }^{31} \mathrm{P}$ NMR spectra for all synthetic compounds; NOESY spectra for 2; crystallographic details. This material is available free of charge via the Internet at http://pubs.acs.org. 


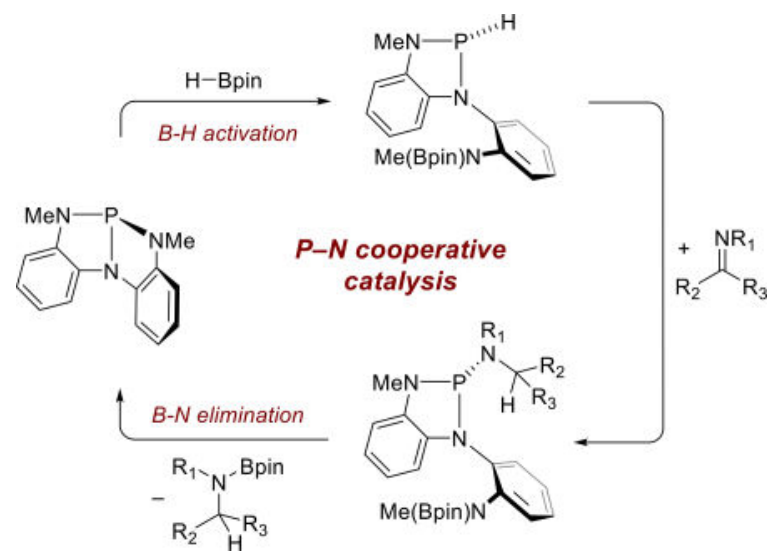

\section{Introduction}

Bifunctional reactivity involving the cooperative action of donor and acceptor functionality juxtaposed within close molecular proximity is a potent strategy for the modification of chemical bonds. The power and breadth of this approach is well-exemplified in the many cases of metal-ligand cooperativity now evident in transition metal catalysis, ${ }^{1,2}$ where activation of a substrate covalent bond arises from the intimate participation and mutual modification of both a reactive metal center and supporting ligand. The documented scope of this reactivity mode across diverse transition metals and ligand structures ${ }^{3-7}$ is indicative of its generality.

Though less commonly described as such, aspects of ligand cooperativity are equally evident in chemistry of the main group; recent stoichiometric examples from Groups $2,{ }^{8} 13,{ }^{9,10}$ $14,{ }^{11,12}$ and $15^{13}$ are representative. These observations regarding main group elementligand cooperativity contribute to ongoing interest into the qualitative connections between reactivity of the transition metals and main group. ${ }^{14}$ In a compelling application of such stoichiometric reactivity to catalysis, Berben has described the cooperative metal-ligand reactivity of aluminum-bis(imino)pyridine compounds in catalytic amine ${ }^{15}$ and formic $\operatorname{acid}^{16}$ dehydrogenation.

We have recently reported on the preparation and reactivity of geometrically deformed phosphorous triamide 1 (Figure 2). ${ }^{17}$ By virtue of the geometric constraint imposed by the triamide ligand, $C_{S}$-symmetric $\mathbf{1}$ exhibits an anomalously low nucleophilic reactivity, but instead demonstrates potent biphilic reactivity as exemplified in the reversible oxidative addition-reductive elimination of $\mathrm{E}-\mathrm{H}$ bonds $(\mathrm{E}=-\mathrm{OR}$, $-\mathrm{NHR})$ to the phosphorus center. Mechanistically, we have shown that the overall oxidative addition proceeds in stepwise phosphorus-ligand cooperative fashion, wherein the protic E-H substrate adds initially across one $\mathrm{P}-\mathrm{N}$ linkage to give a $\sigma^{3}-\mathrm{P}$ intermediate $(\mathbf{A})$ in which a new $\mathrm{P}-\mathrm{E}$ bond is formed and the resultant proton is accommodated on a methylanilide nitrogen (Figure 1, top). Subsequent intramolecular $\sigma^{3} \rightarrow \sigma^{5}$ ring-chain tautomerism then affords the final oxidative addition product $\mathbf{B}$. 
In view of this precedent, we considered the possible outcome from an analogous phosphorus-ligand cooperative activation but with formally hydridic E-H substrates (Figure 1 , bottom). The difference in substrate polarization could be expected to invert the sense of E-H addition to 1, with hydride translocating to the phosphorus center and the attendant $\mathrm{E}^{+}$ fragment migrating to ligand nitrogen. This mode of activation would result in formation of a $P$-hydrido-1,3,2-diazaphospholene (C), a class of compound that Gudat ${ }^{18}$ has shown to exhibit significant hydridic reactivity and that Kinjo ${ }^{19}$ and most recently Speed ${ }^{20}$ have capitalized on in catalysis. We wished to ascertain whether interfacing these elementary reactivities with a subsequent group transfer from the pendant $N$-methylanilide with regeneration of $\mathbf{1}$ would permit an overall catalytic $\mathrm{E}-\mathrm{H}$ transfer via a new $\mathrm{P}-\mathrm{N}$ cooperative scheme.

We report here the realization of the foregoing postulated phosphorus-ligand cooperative scheme within the context of borane $\mathrm{B}-\mathrm{H}$ addition to phosphorous triamide $\mathbf{1}$. We further show that this elementary mode of borane activation can be advanced to a catalytic B-H transfer application (imine hydroboration). Through spectroscopic and kinetic analyses, we validate the operation of the phosphorus-ligand cooperativity in which the reversible addition and elimination across a reactive $\mathrm{P}-\mathrm{N}$ linkage drives catalysis. These results further expand the scope of ligand cooperative catalytic reactivity in the main group and portend a broader opportunity for the deliberate design of bifunctional, ligand cooperative catalysts based on inexpensive $p$-block elements.

\section{Results}

\subsection{Stoichiometric Reactivity}

\subsubsection{Formation and Spectroscopic Characterization of P-hydrido-1,3,2-} diazaphospholene 2-To test the hypothesis that $\mathbf{1}$ would exhibit bifunctional, phosphorus-ligand cooperative activation of $\mathrm{B}-\mathrm{H}$ bonds, a solution of $\mathbf{1}\left(0.13 \mathrm{M}\right.$ in $\left.\mathrm{C}_{6} \mathrm{D}_{6}\right)$ was treated with one equivalent of pinacolborane (HBpin) (Scheme 1). Over the course of 12 $\mathrm{h}$ at $50{ }^{\circ} \mathrm{C},{ }^{31} \mathrm{P}$ NMR spectra indicated the full consumption of $\mathbf{1}(\delta 159.9 \mathrm{ppm})$ and formation of a major new phosphorus containing product (2) with a chemical shift $\delta 84.2$ ppm (d, $J=146 \mathrm{~Hz})$. Both the ${ }^{31} \mathrm{P}$ chemical shift and multiplicity are suggestive of a tricoordinate phosphorus species with a direct $\mathrm{P}-\mathrm{H}$ linkage. The presence of a $\mathrm{P}-\mathrm{H}$ moiety is further supported by ${ }^{1} \mathrm{H}$ NMR spectra of species $\mathbf{2}$, which display a new doublet at $\delta 6.88$ ppm with complementary coupling $(J=146 \mathrm{~Hz})$ to that observed in ${ }^{31} \mathrm{P}$ NMR spectra. Additionally, the ${ }^{1} \mathrm{H}$ NMR spectra show an apparent decrease in molecular symmetry of $\mathbf{2}$ relative to $\mathbf{1}$; the previously homotopic $\mathbf{N}$-methyl groups from $\mathbf{1}$ are present in $\mathbf{2}$ as two distinct resonances $(\delta 3.05,2.55 \mathrm{ppm})$. Only one of the $N$-methyl resonances $(\delta 2.55 \mathrm{ppm})$ displays ${ }^{3} J_{\mathrm{P}-\mathrm{H}}$ coupling $(J=15 \mathrm{~Hz})$, suggesting release of one $N$-methylanilide substituent from the phosphorus center of $\mathbf{1}$ upon reaction with HBpin. The ${ }^{11} \mathrm{~B}$ NMR signal of $\mathbf{2}$ was also identified at $24.2 \mathrm{ppm}$.

Additional information regarding the overall composition of 2 emerges from twodimensional NOESY spectra (Figure 2). Cross peaks indicate ${ }^{1} \mathrm{H}-{ }^{1} \mathrm{H}$ NOE correlation signals between $\mathrm{H}^{1}$ (i.e. $\mathrm{P}-\mathrm{H}$ ) and both $\mathrm{H}^{6}$ and $\mathrm{H}^{7}$ ( $N$-methyl C-Hs), confirming the open 
structure of the ligand framework. Also, the correlation between $\mathrm{H}^{8}$ (pinacol methyl C-Hs) with both $\mathrm{H}^{1}$ and $\mathrm{H}^{7}$ confirm the presence of the Bpin moiety on the pendant $\mathrm{N}$ -

methylanilide arm. Taken together, these spectral data are consistent with the formulation of 2 as a $P$-hydrido-1,3,2-diazaphospholene arising from $\mathrm{P}-\mathrm{N}$ cooperative activation of the $\mathrm{B}-$ $\mathrm{H}$ bond of HBpin. The atropisomeric diastereomers, which were previously observed in the analogous compounds $\mathbf{A}$, are not resolved spectroscopically for $\mathbf{2}$ presumably as function of the small size of the P-H moiety. Compound 2 is solution stable $(0.12 \mathrm{M}, 95 \%$ NMR yield), further evolving to $\sigma^{5}-\mathrm{P}$ hydridophosphoranes upon prolonged standing in the presence of excess HBpin. We have not succeeded to date in isolating single crystals of $\mathbf{2}$ for $\mathrm{x}$-ray analysis despite repeated attempts.

2.1.2. Kinetic Study of the B-H Activation Reaction-Kinetic analyses were conducted to elucidate the reaction rate and molecularity of the phosphorus-ligand cooperative B-H activation. The reaction of $\mathbf{1}\left(78 \mathrm{mM}\right.$ in $\mathrm{C}_{6} \mathrm{D}_{6}$ ) with excess $\mathrm{HBpin}$ (15 equiv) was monitored via ${ }^{1} \mathrm{H}$ NMR as a function of time $\left(25^{\circ} \mathrm{C}, 1,3,5-(\mathrm{MeO}){ }_{3} \mathrm{C}_{6} \mathrm{H}_{3}\right.$ internal standard), which displayed pseudo-first order dependence on 1 (Figure 3A). Plots of $k_{\mathrm{obs}}$ vs. [HBpin $]_{0}$ (Figure 3B) demonstrate a linear relationship over the concentration range $0.78 \mathrm{M}$ $\leq$ HBpin] $\leq 2.73 \mathrm{M}$, thus establishing an overall second order reaction rate law for addition of HBpin to 1 (eq $1, k=4.76 \times 10^{-5} \mathrm{M}^{-1} \mathrm{~s}^{-1}$ at $25^{\circ} \mathrm{C}$ ) in accord with the notion of direct bimolecular phosphorus-ligand cooperative activation of the $\mathrm{B}-\mathrm{H}$ bond.

$$
\nu=-k_{\mathrm{obs}}[\mathrm{HBpin}]=-k[\mathbf{1}][\mathrm{HBpin}]
$$

2.1.3. Hydridic Reactivity of $\mathbf{2}$ - Alkylhalide Reduction-In line with the rationale from Gudat regarding the impact of hyperconjugative effects on 1,3,2-diazaphospholene reactivity, ${ }^{21}$ we wished to evaluate the hydridic behavior of $\mathbf{2}$. Indeed, NBO charge analysis implicates a hydridic nature of the $\mathrm{P}-\mathrm{H}$ moiety in 2 (atomic charge of -0.11). In agreement with this analysis, the addition of chloroform to a solution of $2\left(78 \mathrm{mM}\right.$ in $\left.\mathrm{C}_{6} \mathrm{D}_{6}\right)$ resulted in conversion over the course of $6 \mathrm{~h}$ to a new compound ( ${ }^{31} \mathrm{P}$ NMR $\left.\delta 146.4 \mathrm{ppm}\right)$ consistent with the assignment as $P$-chloro-1,3,2-diazaphospholene $\mathbf{3}$ (Scheme 2). In an alternative preparation, compound $\mathbf{3}$ may be accessed directly from $\mathbf{1}$ by treatment with HBpin in chloroform solution. Surprisingly in this latter reaction, compound $\mathbf{2}$ is not observed to accumulate in solution as a persistent intermediate. This observation suggests that the reaction consuming $\mathbf{2}$ (with the halogenated substrate) is more rapid than the reaction generating $\mathbf{2}$ (from $\mathbf{1}$ by HBpin activation), consistent with the potent hydricity of $P$ hydrido-1,3,2-diazaphospholenes, such as $\mathbf{2}$.

Crystalline samples of $\mathbf{3}$ suitable for $\mathrm{x}$-ray diffraction were prepared by crystallization from $\mathrm{CH}_{2} \mathrm{Cl}_{2}$ /pentane solution. The molecular structure (Figure 4) confirms the tricoordinate phosphorus local environment with pendant $\mathrm{N}(\mathrm{Bpin})$ moiety, supporting the analogous structural assignment for $\mathbf{2}$. Compound $\mathbf{3}$ displays a small displacement $(0.251 \AA)$ of phosphorus from the $\mathrm{C}_{2} \mathrm{~N}_{2}$ plane and a rather long $\mathrm{P}-\mathrm{Cl}$ bond length (2.276(1) $\mathrm{A}$, compare $2.180(4) \AA$ for $\left.\left(\mathrm{Me}_{2} \mathrm{~N}\right)_{2} \mathrm{PCl}^{22}\right)$, indicative of hyperconjugative $\mathrm{n}(\pi) \rightarrow \sigma^{*}$ overlap as has been 
noted in related compounds by Gudat. It is reasonable to assume that compound 2 experiences similar electronic interactions that underpin its hydridic reactivity.

2.1.4. Hydridic Reactivity of $\mathbf{2}$ - Imine Reduction-To further evaluate its hydricity with respect to organic substrates, compound $\mathbf{2}$ was treated with $\mathrm{N}$-tosylbenzaldimine at rt in benzene solution (Scheme 3) resulting in complete conversion to 4 ( ${ }^{31} \mathrm{P}$ NMR $\left.\delta 92.6 \mathrm{ppm}\right)$. $\mathrm{X}$-ray crystallography confirms the incorporation of the imine fragment through a formal hydrophosphination giving a triamide local environment about tricoordinate phosphorus with the Bpin moiety on a pendant $N$-methylanilide arm (Figure 5). As above, compound 4 may also be accessed directly from 1 by treatment with $\mathrm{PhHC}=\mathrm{NT}$ s and HBpin at ambient temperature, where $\mathbf{2}$ is a presumed but unobservable intermediate. Compound $\mathbf{4}$ is a stable species in both the solid state and solution; no decomposition is observed after heating a benzene solution at $60{ }^{\circ} \mathrm{C}$ for $48 \mathrm{~h}$.

2.1.5. Evidence for Cooperative B-N Elimination-In contrast to the simple hydrophosphination of $N$-tosylbenzaldimine, reaction of 2 with an $N$-alkyl benzaldimine results in a markedly different outcome. Treatment of a benzene solution of $\mathbf{2}$ with $N$-benzyl p-methoxybenzaldimine (5) at ambient temperature resulted in the consumption of $\mathbf{2}$ and, unexpectedly, the formation of $\mathbf{1}$ (Scheme 4). ${ }^{1} \mathrm{H}$ NMR spectra confirm the concomitant formation of hydroboration product 7 under these conditions.

In situ ${ }^{31} \mathrm{P}$ NMR monitoring of the above reaction progress provides a window into this transformation (Figure 6). An initial solution of 2, prepared in situ from reaction of $\mathbf{1}$ with HBpin in $\mathrm{C}_{6} \mathrm{D}_{6},{ }^{23}$ was treated with imine 5. As the reaction progresses (Figure 6b,c), the concentration of $\mathbf{2}$ was observed to decrease while the concentration of $\mathbf{1}$ was simultaneously observed to increase. Also evident in these spectra is the appearance of a transient minor peak $\delta 105.1 \mathrm{ppm}$. In view of the chemical shift of this signal, we considered that this species might correspond to the phosphorous triamide $\mathbf{6}$ from hydrophosphination of 5 with 2. Indeed, independent synthesis of $\mathbf{6}$ from treatment of $\mathbf{3}$ with $N$-benzyl- $N-(p$ methoxyphenyl)methanamine (Scheme 5) gives the same ${ }^{31} \mathrm{P}$ NMR signal $\delta 105.1 \mathrm{ppm}$. Consistent with the above observations, $\mathbf{6}$ is metastable in solution but not isolable. Instead, 6 decomposes cleanly to 1 , proceeding to completion within $60 \mathrm{~h}$ at ambient temperature ( ${ }^{31} \mathrm{P}$ NMR spectra, Figure 7). Correspondingly, ${ }^{1} \mathrm{H}$ NMR spectra confirm the formation of the N-borylamine product 7 by $\mathrm{B}-\mathrm{N}$ elimination from 6.

Although $\mathbf{6}$ is not isolable itself, a related phosphorous triamide $\mathbf{8}(\delta 91.3 \mathrm{ppm})$ can be prepared by treatment of $\mathbf{3}$ with benzylamine as depicted in Scheme 6 . The composition of this compound was unambiguous proven by X-ray diffraction analysis of single crystalline samples (Figure 8). The similarity in ${ }^{31}$ P NMR chemical shifts between isolable 8 and transient 6 supports the assignment of the latter as the phosphorous triamide depicted in Scheme 4 . In a further analogy to $\mathbf{6}$, compound $\mathbf{8}$ can be directly converted to $\mathbf{1}$ upon heating $\left(50{ }^{\circ} \mathrm{C}, 48 \mathrm{~h}\right.$ ) with liberation of $\mathrm{N}$-boryl benzylamine 9 . Taken together, the totality of these experiments demonstrates that the $N$-boryl benzylamines are generated from the phosphorous triamide intermediates via a ligand-phosphorus cooperative pathway. 
2.1.6. Kinetic Study of the B-N Elimination Reaction-The rate of the conversion from $\mathbf{6}$ to $\mathbf{1}$ is suitable for NMR monitoring of kinetic reaction progress. Compound $\mathbf{6}$ was prepared in solution as depicted in Scheme 5, with purification by rapid filtration over celite to eliminate triethylammonium chloride. The decay of $\mathbf{6}$ was then monitored at ambient temperature by ${ }^{1} \mathrm{H}$ NMR spectroscopy to greater than $75 \%$ conversion (Figure 9 ). The linear relationship between $\ln [\mathbf{6}]$ and time (Figure 9 , inset) demonstrates first-order behavior, as would be expected for a unimolecular decomposition of $\mathbf{6}$. The extracted rate constant $(k=$ $0.04 s^{-1}$ ) is independent of absolute concentration within the range $0.58 \mathrm{mM}<[6]<3.26$ $\mathrm{mM}$. These results are fully consistent with a ligand cooperative intramolecular transfer of the boryl unit from the $N$-methylanilide arm to the $N$-benzyl- $N-(p-$ methoxyphenyl)methanamine fragment, elimination of $N$-borylamine 7, and reconstitution of a $\mathrm{P}-\mathrm{N}$ bond in the conversion of $\mathbf{6}$ to $\mathbf{1}$.

\subsection{Catalytic Reactivity}

In view of the foregoing stoichiometric reactivities, we pursued investigations of hydroboration reactions catalyzed by 1 . In an initial reaction, a benzene solution of $\mathrm{N}$-benzyl $p$-anisaldimine 5 (1 equiv) and HBpin (1 equiv) was exposed to $10 \mathrm{~mol} \%$ of $\mathbf{1}$ at $50{ }^{\circ} \mathrm{C}$. Under these conditions, imine 5 was completely converted to the hydroboration product 7 over the course of $24 \mathrm{~h}$ (eq 2). Control reactions between 5 and HBpin under otherwise identical conditions but omitting catalytic $\mathbf{1}$ show less than $15 \%$ conversion (eq 3 ), consistent with a transformation that is indeed under catalyst control.
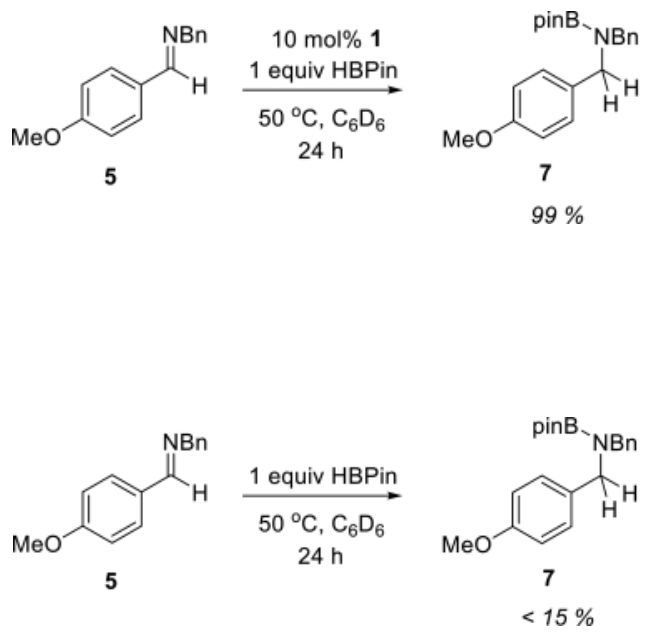

(2)

(3)

In situ spectral monitoring experiments of the catalytic reaction was conducted to further substantiate the action of $\mathbf{1}$ during catalysis. Following mixing of $\mathbf{5}$, HBpin, and $10 \mathrm{~mol} \% \mathbf{1}$ in $\mathrm{C}_{6} \mathrm{D}_{6}$ at $50{ }^{\circ} \mathrm{C}$ in a thermostatted probe, a ${ }^{31} \mathrm{P}$ NMR spectrum indicates the presence of small quantities of $\mathbf{2}$, formed at the expense of the initial concentration of $\mathbf{1}$. At subsequent intermediate time points $(t=0.5-12 \mathrm{~h})$, the concentrations of 2 showed no significant change. As the transformation progressed over the next $24 \mathrm{~h}$, continued production of the corresponding hydroboration product $\mathbf{7}$ could be observed by ${ }^{1} \mathrm{H}$ NMR spectra. Catalyst $\mathbf{1}$, 
although diminished, was never completely consumed. The existence of $\mathbf{1}$ during the entire course of catalytic reaction as opposed to its total conversion to $\mathbf{2}$ in stoichiometric reaction suggested again that the reduction of the imine by $\mathbf{2}$ leads to an ephemeral intermediate $\mathbf{5}$ (see Scheme 4) which decomposes to afford 1 and the hydroboration product.

Under the aforementioned catalytic conditions, imines displaying an array of structural variations are reduced catalytically and produce the corresponding hydroboration products with good to excellent yields. As depicted in eq 4, a range of aldimines are tolerated, including those with $N$-aryl (10) and $N$-alkyl (11) substitution, and electronically diverse (14 - 18) and sterically demanding (19) $C$-substituents. Ketimines are similarly reduced under catalytic conditions $(\mathbf{2 1}-\mathbf{2 3})$. Lower yields in the reduction of ketimines are probably caused by a steric effect.

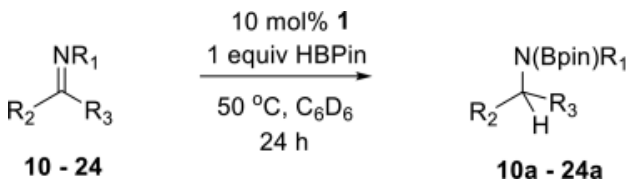

\begin{tabular}{lllll}
\hline $\mathbf{1 0}$ & $\mathrm{R}_{1}=\mathrm{Ph}$ & $\mathrm{R}_{2}=\mathrm{Ph}$ & $\mathrm{R}_{3}=\mathrm{H}$ & $99 \% \mathrm{y}$ \\
11 & $\mathrm{R}_{1}=\mathrm{Bn}$ & $\mathrm{R}_{2}=p-\mathrm{BrC}_{6} \mathrm{H}_{4}$ & $\mathrm{R}_{3}=\mathrm{H}$ & $73 \% \mathrm{y}$ \\
$\mathbf{1 2}$ & $\mathrm{R}_{1}=p-\mathrm{MeC}_{6} \mathrm{H}_{4}$ & $\mathrm{R}_{2}=p-\mathrm{MeC}_{6} \mathrm{H}_{4}$ & $\mathrm{R}_{3}=\mathrm{H}$ & $88 \% \mathrm{y}$ \\
$\mathbf{1 3}$ & $\mathrm{R}_{1}=p-\mathrm{OMeC}_{6} \mathrm{H}_{4}$ & $\mathrm{R}_{2}=\mathrm{Ph}$ & $\mathrm{R}_{3}=\mathrm{H}$ & $76 \% \mathrm{y}$ \\
$\mathbf{1 4}$ & $\mathrm{R}_{1}=p-\mathrm{OMeC}_{6} \mathrm{H}_{4}$ & $\mathrm{R}_{2}=p-\mathrm{FC}_{6} \mathrm{H}_{4}$ & $\mathrm{R}_{3}=\mathrm{H}$ & $94 \% \mathrm{y}$ \\
$\mathbf{1 5}$ & $\mathrm{R}_{1}=p-\mathrm{OMeC}_{6} \mathrm{H}_{4}$ & $\mathrm{R}_{2}=1-\mathrm{naphthyl}$ & $\mathrm{R}_{3}=\mathrm{H}$ & $99 \% \mathrm{y}$ \\
$\mathbf{1 6}$ & $\mathrm{R}_{1}=p-\mathrm{OMeC}_{6} \mathrm{H}_{4}$ & $\mathrm{R}_{2}=m-\mathrm{CF}_{3} \mathrm{C}_{6} \mathrm{H}_{4}$ & $\mathrm{R}_{3}=\mathrm{H}$ & $96 \% \mathrm{y}$ \\
$\mathbf{1 7}$ & $\mathrm{R}_{1}=p-\mathrm{OMeC}_{6} \mathrm{H}_{4}$ & $\mathrm{R}_{2}=p-\mathrm{OMeC}_{6} \mathrm{H}_{4}$ & $\mathrm{R}_{3}=\mathrm{H}$ & $64 \% \mathrm{y}$ \\
$\mathbf{1 8}$ & $\mathrm{R}_{1}=p-{\mathrm{CF} 3 \mathrm{C}_{6} \mathrm{H}_{4}}$ & $\mathrm{R}_{2}=p-\mathrm{OMeC} 6 \mathrm{H}_{4}$ & $\mathrm{R}_{3}=\mathrm{H}$ & $99 \% \mathrm{y}$ \\
$\mathbf{1 9}$ & $\mathrm{R}_{1}=p-\mathrm{OMeC} \mathrm{H}_{4}$ & $\mathrm{R}_{2}=\mathrm{mesityl}$ & $\mathrm{R}_{3}=\mathrm{H}$ & $77 \% \mathrm{y}$ \\
$\mathbf{2 0}$ & $\mathrm{R}_{1}=p-\mathrm{FC} \mathrm{H}_{4}$ & $\mathrm{R}_{2}=\mathrm{Ph}$ & $\mathrm{R}_{3}=\mathrm{H}$ & $91 \% \mathrm{y}$ \\
$\mathbf{2 1}$ & $\mathrm{R}_{1}=\mathrm{Ph}$ & $\mathrm{R}_{2}=\mathrm{Ph}$ & $\mathrm{R}_{3}=\mathrm{Me}$ & $48 \% \mathrm{y}$ \\
$\mathbf{2 2}$ & $\mathrm{R}_{1}=\mathrm{Bn}$ & $\mathrm{R}_{2}=\mathrm{Ph}$ & $\mathrm{R}_{3}=\mathrm{Ph}$ & $64 \% \mathrm{y}$ \\
$\mathbf{2 3}$ & $\mathrm{R}_{1}=\mathrm{Bn}$ & $\mathrm{R}_{2}=\mathrm{Ph}$ & $\mathrm{R}_{3}=\mathrm{Me}$ & $94 \% \mathrm{y}$ \\
$\mathbf{2 4}$ & $\mathrm{R}_{1}=\mathrm{Ph}$ & $\mathrm{R}_{2}=p-\mathrm{Ts}$ & $\mathrm{R}_{3}=\mathrm{H}$ & $<5 \% \mathrm{y}$ \\
\hline
\end{tabular}

Consistent with the observed thermal stability of $N$-sulfonyl derivative 4 (Sect. 2.1.4), $N$ - $p$ toluenesulfonyl aldimines $(\mathbf{2 4})$ are not suitable substrates for catalytic reduction. In this circumstance, presumably catalytic turnover is prohibited by the failure of an intermediate 4 to undergo cooperative elimination of $N$-borylated product with regeneration of catalyst $\mathbf{1}$. This negative result supports the notion that the $\mathrm{P}-\mathrm{N}$ cooperativity reactivity demonstrated in stoichiometric transformations (Sect. 2.1) is both necessary and operative in catalytic reactions. 


\section{Discussion}

In line with ongoing investigations into the catalytic function of nontrigonal tricoordinate phosphorus compounds, we find that compound $\mathbf{1}$ is a competent nonmetal reactant for the activation of the B-H bond in HBpin, and for subsequent catalytic hydroboration of imines. The sum of the experimentally validated stoichiometric transformations establishes the basis for the proposed $\mathrm{P}-\mathrm{N}$ cooperative mechanism of catalytic hydroboration by $\mathbf{1}$, as depicted in Scheme 7: (1) addition of HBpin to $\mathbf{1}$ generates intermediate $\mathbf{2}$ via a bimolecular cooperative mechanism, (2) formal insertion of imine substrate to the $\mathrm{P}-\mathrm{H}$ of $\mathbf{2}$ giving a phosphorous triamide 25, and (3) intramolecular boryl transfer to eliminate $N$-borylamine 26 with regeneration of catalyst $\mathbf{1}$ and closure of the catalytic cycle.

Borane B-H activation is, of course, well-known with transition metals both via oxidative addition ${ }^{24}$ and metal-ligand cooperativity ${ }^{25}$; a great many catalytic hydroboration applications are based on these fundamental bond activation reactions. ${ }^{26}$ Main group B-H activation is also precedented, for instance 1,1-oxidative addition by carbenes. ${ }^{27}$ More common, though, are formally heterolytic reactivity modes, either FLP-type activation ${ }^{28}$ in the presence of Lewis bases or formally metathetical transformations across polarized $\sigma$ bonds, ${ }^{29}$ where catalytic applications are known. ${ }^{30}$ Also, although not rigorously involving B-H activation, the Corey-Bakshi-Shibata protocol warrants mention in conjunction with a discussion of bifunctional main group catalyzed hydroboration. ${ }^{31}$ Nikonov $^{32}$ and Kinjo ${ }^{33}$ have recently reviewed various aspects of main group catalyzed reduction chemistry.

A theme emerging from our study of $\mathbf{1}$ and related distorted structures concerns the extent to which descent from local threefold symmetry about tricoordinate phosphorus results in increased electrophilic character at P. Enthalpic (strain) arguments have been advanced in related systems that account for this observation, ${ }^{34}$ although electronic effects are also very likely to play an equally decisive role. In the case of $\mathbf{1}$, this mode of reactivity is accentuated as a function of the geometric constraint imposed by the triamide support framework. Whereas we had previously probed the increased electrophilic reactivity at phosphorus by reaction of $\mathbf{1}$ with protic $\mathrm{E}-\mathrm{H}$ substrates $(\mathrm{E}=\mathrm{OR}, \mathrm{NHR}),{ }^{35}$ here we access a regioreversal by reaction with a hydridic $\mathrm{E}-\mathrm{H}(\mathrm{E}=\mathrm{Bpin})$ compound. In this event, the acceptance of a hydride at phosphorus results in boryl transfer to the pendant $N$-methylanilide with P-N scission. Kinetics experiments demonstrate that the B-H reaction occurs in a bimolecular fashion, effectively a net $\sigma$-bond metathesis. In view of the ubiquity of phosphine-borane dative interactions, the regioselectivity of the $\mathrm{B}-\mathrm{H}$ activation bears special mention; presumably both the weak $P$-nucleophilicity of $\mathbf{1}$ and weak $B$-electrophilicity of HBpin disfavor the common $\mathrm{P} \rightarrow \mathrm{B}$ interaction.

The $P$-hydrido-1,3,2-diazaphospholene intermediate 2 arising from $\mathrm{P}-\mathrm{N}$ cooperative activation of the B-H bond in HBpin serves as a point of intersection with previous studies by Gudat, Kinjo, and Speed. Gudat has demonstrated the controlling role of hyperconjugative effects and $\pi-\sigma^{*}$ aromaticity in the structure and reactivity of $P$-substituted diazaphos-pholenes, phenomena that are manifest in a marked reactivity of the $\mathrm{P}-\mathrm{H}$ moiety toward formal imine insertion as in $\mathbf{2}$. Similar electronic effects presumably also underpin the subsequent intramolecular boryl transfer reaction that leads to elimination of $\mathrm{N}$ - 
borylamine products $\mathbf{2 6}$ and reforms $\mathbf{1}$. This latter step is rapid under catalytic conditions as a function of the enforced intramolecularity; consequently, throughput via intermediates 2 and $\mathbf{2 5}$ is fast and $\mathbf{1}$ represents the resting state of the catalytic cycle. By way of contrast, recently reported diazaphospholene catalysts are devoid of possible ligand cooperativity, forcing the formation of reactive $P$-hydrido-1,3,2-diazaphospholenes to be turnover limiting. The $\mathrm{P}-\mathrm{N}$ cooperative function of $\mathbf{1}$ is therefore a distinctive and essential aspect of its catalytic performance. Overall, the proposed mechanistic framework provides an entry point for next-generation optimization of $\mathrm{P}-\mathrm{N}$ cooperative catalysis with $\mathbf{1}$ by deliberate targeting of individual steps for acceleration through rational modification and substituent effects.

\section{Conclusions}

Distorted phosphorous triamide $\mathbf{1}$ was shown to be a catalyst for the hydroboration of imines, and the mechanistic details underpinning this observation have been eludicated. The reactivity arises from the cooperative action of an electrophilic tricoordinate phosphorus center with a proximal basic $N$-methylanilide nitrogen within the distorted molecular environment imposed by the triamide supporting structure. The phosphorus-ligand cooperative bimolecular pathway is involved in both the initial $\mathrm{B}-\mathrm{H}$ activation and the restoration of distorted phosphabicyclic structure of $\mathbf{1}$ following substrate reduction. The ability of distorted phosphorous triamide $\mathbf{1}$ to catalyze B-H transfer through a P-N ligand cooperative mechanism suggests further opportunity for targeted design of novel main group catalysts. On the basis of the described mechanistic model, new bifunctional $P$-based catalysts are being developed with potential applications across a range of $\mathrm{E}-\mathrm{H}$ transfer chemistries and will be reported in due course.

\section{Experimental Section}

A full description of the general experimental methods, including preparation and purification of starting materials, can be found in the Supporting Information.

\section{Synthesis of 2}

Under nitrogen atmosphere, pinacolborane $(15 \mathrm{mg}, 0.12 \mathrm{mmol})$ was mixed with a $\mathrm{C}_{6} \mathrm{D}_{6}$ solution (1 mL) of compound $1(30 \mathrm{mg}, 0.12 \mathrm{mmol})$ in a sealable threaded NMR tube. The mixture was stirred at $50{ }^{\circ} \mathrm{C}$ for $12 \mathrm{~h}$ to afford crude 2 (estimated purity $95 \%$ by ${ }^{1} \mathrm{H}$ NMR). ${ }^{1} \mathrm{H}$ NMR $\left(\mathrm{C}_{6} \mathrm{D}_{6}, 500 \mathrm{MHz}\right): \delta 7.29(\mathrm{~d}, 1 \mathrm{H}, J=7.8 \mathrm{~Hz}), 7.20(\mathrm{~d}, 1 \mathrm{H}, J=7.8 \mathrm{~Hz}), 7.07(\mathrm{~d}$, $1 \mathrm{H}, J=7.7 \mathrm{~Hz}), 6.92-6.77(\mathrm{~m}, 4 \mathrm{H}), 6.86\left(\mathrm{~d}, 1 \mathrm{H},{ }^{1} J_{\mathrm{P}-\mathrm{H}}=146.3 \mathrm{~Hz}\right), 6.52\left(\mathrm{~d},{ }^{1} \mathrm{H}, J=7.8\right.$ $\mathrm{Hz}), 3.05(\mathrm{~s}, 3 \mathrm{H}), 2.85$ (d, 3H, $J=12.8 \mathrm{~Hz}), 1.05(\mathrm{~s}, 12 \mathrm{H}) \mathrm{ppm} .{ }^{31} \mathrm{P}$ NMR $\left(\mathrm{C}_{6} \mathrm{D}_{6}, 202 \mathrm{MHz}\right)$ : $\delta 84.2(\mathrm{~d}, J=146 \mathrm{~Hz})$ ppm. MS (ESI) $\mathrm{C}_{20} \mathrm{H}_{27} \mathrm{BN}_{3} \mathrm{O}_{2} \mathrm{P}\left(\mathrm{M}^{+}\right)$calc'd: 383.1934; found: 383.1938.

\section{Synthesis of 3}

Under nitrogen atmosphere, pinacolborane $(50 \mathrm{mg}, 0.39 \mathrm{mmol})$ was added into a $\mathrm{CHCl}_{3}$ solution $(2 \mathrm{~mL})$ of compound $1(100 \mathrm{mg}, 0.39 \mathrm{mmol})$ and the solution was stirred under room temperature. After $12 \mathrm{~h}$, all volatiles were removed in vacuo and the remaining white solid was recrystallized in pentane to afford 3 as a white crystals $(80 \mathrm{mg}, 70 \%) .{ }^{1} \mathrm{H}$ NMR 
$\left(\mathrm{CDCl}_{3}, 400 \mathrm{MHz}\right): \delta 7.64(\mathrm{~d}, 1 \mathrm{H}, J=8.0 \mathrm{~Hz}), 7.37-7.26(\mathrm{~m}, 3 \mathrm{H}), 7.08(\mathrm{t}, 1 \mathrm{H}, J=8.0 \mathrm{~Hz})$, 7.01-6.97 (m, 2H), 3.39 (d, 3H, $J=16.0 \mathrm{~Hz}), 2.85(\mathrm{~s}, 3 \mathrm{H}), 0.94($ broad s, $12 \mathrm{H}) \mathrm{ppm} .{ }^{13} \mathrm{C}$ NMR $\left(\mathrm{CDCl}_{3}, 100 \mathrm{MHz}\right): \delta 145.0\left(\mathrm{~d},{ }^{2} J_{\mathrm{PC}}=4.0 \mathrm{~Hz}\right), 136.9\left(\mathrm{~d},{ }^{2} J_{\mathrm{PC}}=12.0 \mathrm{~Hz}\right), 132.0(\mathrm{~d}$, $\left.{ }^{2} J_{\mathrm{PC}}=11.0 \mathrm{~Hz}\right), 129.5,129.5,128.8,128.3,125.7,121.5,121.1,111.9,110.0,82.7,37.2$, $29.4\left(\mathrm{~d},{ }^{2} J_{\mathrm{PC}}=18.0 \mathrm{~Hz}\right), 24.2 \mathrm{ppm} .{ }^{31} \mathrm{P} \mathrm{NMR}\left(\mathrm{CDCl}_{3}, 145 \mathrm{MHz}\right): \delta 146.4 \mathrm{ppm} . \mathrm{MS}(\mathrm{ESI})$ $\mathrm{C}_{20} \mathrm{H}_{26} \mathrm{BN}_{3} \mathrm{O}_{2} \mathrm{P}\left(\mathrm{M}^{+}-\mathrm{Cl}\right)$ calc'd: 382.1856 ; found: 382.1859 .

\section{Synthesis of 4}

Under nitrogen atmosphere, a $\mathrm{C}_{6} \mathrm{D}_{6}$ solution of in situ generated $2(1 \mathrm{ml}, 0.24 \mathrm{M})$ was added $N$-tosyl-1-phenylmethanimine ( $64 \mathrm{mg}, 0.24 \mathrm{mmol})$. The mixture was stirred at room temperature for $16 \mathrm{~h}$, all volatiles were removed in vacuo and the resulting white solid was washed with pentane $(60 \mathrm{mg}, 63 \%)$. The solid was then recrystallized in a 10:1 pentane/ $\mathrm{CH}_{2} \mathrm{Cl}_{2}$ solution to obtain the samples for $\mathrm{X}$-ray crystallography. ${ }^{1} \mathrm{H} \mathrm{NMR}\left(\mathrm{C}_{6} \mathrm{D}_{6}, 400\right.$ MHz): $\delta 7.80(\mathrm{~d}, 2 \mathrm{H}, J=7.9 \mathrm{~Hz}), 7.53-7.50(\mathrm{~m}, 2 \mathrm{H}), 7.37$ (d, $1 \mathrm{H}, J=8.0 \mathrm{~Hz}), 7.20-7.07$ (m, $5 \mathrm{H}), 6.93-6.69(\mathrm{~m}, 5 \mathrm{H}), 6.65(\mathrm{~d}, 1 \mathrm{H}, J=7.4 \mathrm{~Hz}), 6.05(\mathrm{~d}, 1 \mathrm{H}, J=7.5 \mathrm{~Hz}), 4.51(\mathrm{~d}, 1 \mathrm{H}, J=$ $15.9 \mathrm{~Hz}), 3.69(\mathrm{~d}, 1 \mathrm{H}, J=15.9 \mathrm{~Hz}), 2.93(\mathrm{~s}, 3 \mathrm{H}), 2.38$ (d, 3H, $J=11.8 \mathrm{~Hz}), 2.07(\mathrm{~s}, 3 \mathrm{H})$, 1.12 (s, $12 \mathrm{H})$ ppm. ${ }^{13} \mathrm{C}$ NMR $\left(\mathrm{C}_{6} \mathrm{D}_{6}, 126 \mathrm{MHz}\right): \delta$ 145.1, 141.6, 139.5, 137.9, 137.7, 137.7, $137.0\left(d,{ }^{2} J_{\mathrm{PC}}=10.1 \mathrm{~Hz}\right), 134.1\left(d,{ }^{2} J_{\mathrm{PC}}=12.6 \mathrm{~Hz}\right), 129.8,129.3,129.1,128.1,126.8$, 126.8, 125.2, 124.2, 119.9, 118.5, 108.6, 107.8, 82.8, 47.9, 36.2, 36.2, 28.6, 28.4, 24.6, 24.4 ppm. ${ }^{31} \mathrm{P}$ NMR $\left(\mathrm{C}_{6} \mathrm{D}_{6}, 145 \mathrm{MHz}\right): \delta 92.6 \mathrm{ppm}$. MS (ESI) $\mathrm{C}_{34} \mathrm{H}_{41} \mathrm{BN}_{4} \mathrm{O}_{4} \mathrm{PS}\left(\mathrm{M}^{+}+\mathrm{H}\right)$ calc'd: 643.2679; found: 643.2685 .

\section{Compound 6 and NMR monitoring of its decay}

Under nitrogen atmosphere, a 1:1 THF/ether solution of $3(30 \mathrm{mg}, 70 \mathrm{mM})$ and an ether solution of $N$-benzyl-1-(4-methoxyphenyl)methanamine (33 mg, $140 \mathrm{mM}$ ) were both cooled to $-30{ }^{\circ} \mathrm{C}$ and then mixed together. The resulting cloudy mixture was quickly filtered through Celite and all volatiles were removed in vacuo to afford crude 5. (NMR yield $70 \%$ ). The product was then dissolved in $\mathrm{C}_{6} \mathrm{D}_{6}$ and the solution was monitored by ${ }^{31} \mathrm{P}$ and ${ }^{1} \mathrm{H}$ $\mathrm{NMR}^{1} \mathrm{H}$ NMR $\left(\mathrm{C}_{6} \mathrm{D}_{6}, 500 \mathrm{MHz}\right): \delta 7.56(\mathrm{~d}, 1 \mathrm{H}, J=11.0 \mathrm{~Hz}), 7.40(\mathrm{~d}, 1 \mathrm{H}, J=11.0 \mathrm{~Hz})$, 7.23-6.80 (m, 12H), $6.80(\mathrm{~d}, 2 \mathrm{H}, J=11.5 \mathrm{~Hz}), 6.67(\mathrm{~d}, 1 \mathrm{H}, J=10.5 \mathrm{~Hz}), 4.25($ broad s, 2H), 3.70 (broad s, 2H), $3.45(\mathrm{~s}, 3 \mathrm{H}), 3.20(\mathrm{~s}, 3 \mathrm{H}), 3.04\left(\mathrm{~d}, 3 \mathrm{H},{ }^{3} J_{\mathrm{PH}}=13.8 \mathrm{~Hz}\right), 1.16($ broad s, 12H) ppm. ${ }^{31} \mathrm{P}$ NMR $\left(\mathrm{C}_{6} \mathrm{D}_{6}, 145 \mathrm{MHz}\right): \delta 105.2 \mathrm{ppm}$.

\section{Synthesis of 8}

Under nitrogen atmosphere, benzyl amine $\left(26 \mathrm{mg}, 0.24 \mathrm{mmol}\right.$ ) was added into a $\mathrm{CH}_{2} \mathrm{Cl}_{2}$ solution of $\mathbf{3}(50 \mathrm{mg}, 120 \mathrm{mM})$. The resulting cloudy solution was quickly filtered through Celite and all volatiles were removed in vacuo to afford crude $\mathbf{8}$. The crude product was recrystallized in a 1:5 dichloromethane:pentane solution to afford $\mathbf{8}$ as a white crystals (40 mg, $71 \%) .{ }^{1} \mathrm{H}$ NMR $\left(\mathrm{CD}_{2} \mathrm{Cl}_{2}, 360 \mathrm{MHz}\right): \delta 7.40-7.21(\mathrm{~m}, 3 \mathrm{H}), 7.08(\mathrm{~d}, 1 \mathrm{H}, J=7.0 \mathrm{~Hz})$, $6.83(\mathrm{t}, 1 \mathrm{H}, J=7.3 \mathrm{~Hz}), 6.68(\mathrm{t}, 1 \mathrm{H}, J=7.6 \mathrm{~Hz}), 6.61(\mathrm{~d}, 1 \mathrm{H}, J=7.5 \mathrm{~Hz}), 6.56(\mathrm{~d}, 1 \mathrm{H}, J=$ $7.5 \mathrm{~Hz}), 3.07$ (d, 3H, $J=10.3 \mathrm{~Hz}), 2.75(\mathrm{~s}, 3 \mathrm{H}) \mathrm{ppm}, 1.17(\mathrm{~s}, 12 \mathrm{H}) .{ }^{31} \mathrm{P} \mathrm{NMR}\left(\mathrm{CD}_{2} \mathrm{Cl}_{2}, 145\right.$ $\mathrm{MHz}): \delta 91.34$ ppm. ${ }^{13} \mathrm{C} \mathrm{NMR}\left(\mathrm{CD}_{2} \mathrm{Cl}_{2}, 125 \mathrm{MHz}\right): \delta 144.5,143.9,140.9,129.3,129.0$, $128.3\left(d,{ }^{2} J_{\mathrm{PC}}=11.3 \mathrm{~Hz}\right), 127.4,127.0,126.8,126.5,126.2,125.2,118.7,117.3,106.0$, 
82.6, 46.4, 44.8, 35.9, $29.0\left(d,{ }^{2} J_{\mathrm{PC}}=21.2 \mathrm{~Hz}\right), 24.3 \mathrm{ppm}$. MS (ESI) $\mathrm{C}_{27} \mathrm{H}_{35} \mathrm{BN}_{4} \mathrm{O}_{2} \mathrm{P}\left(\mathrm{M}^{+}\right.$ $+\mathrm{H})$ calc'd: 489.2591 ; found 489.2595 .

\section{Supplementary Material}

Refer to Web version on PubMed Central for supplementary material.

\section{Acknowledgments}

The stoichiometric reactivity of $\mathbf{1}$ with HBpin was supported under NSF award CHE-1724505. The catalytic hydroboration studies were supported under NIH grant GM114547. A.T.R. gratefully acknowledges additional support from the Alfred P. Sloan Foundation and Amgen. We thank Dr. Nicole L. Dunn (PSU) for pre-liminary experiments.

\section{References}

1. Khusnutdinova JR, Milstein D. Angew. Chem. Int. Ed. 2015; 54:12236-12273.

2. Trincado, M., Grützmacher, H. Cooperative Catalysis. Peters, R., editor. Wiley-VCH Verlag GmbH \& Co. KGaA; 2015. p. 67-110.

3. Gunanathan C, Milstein D. Acc. Chem. Res. 2011; 44:588-602. [PubMed: 21739968]

4. Zell T, Milstein D. Acc. Chem. Res. 2015; 48:1979-1994. [PubMed: 26079678]

5. Koren-Selfridge L, Londino HN, Vellucci JK, Simmons BJ, Casey CP, Clark TB. Organometallics. 2009; 28:2085-2090.

6. Schneider S, Meiners J, Askevold B. Eur. J. Inorg. Chem. 2012; 2012:412-429.

7. (a) Hashiguchi S, Fujii A, Takehara J, Ikariya T, Noyori R. J. Am. Chem. Soc. 1995; 117:75627563.(b) Fujii A, Hashiguchi S, Uematsu N, Ikariya T, Noyori R. J. Am. Chem. Soc. 1996; 118:2521-2522.(c) Uematsu N, Fujii A, Hashiguchi S, Ikariya T, Noyori R. J. Am. Chem. Soc. 1996; 118:4916-4917.

8. (a) Arrowsmith M, Hadlington TJ, Hill MS, Kociok-Köhn G. Chem. Commun. 2012; 48:45674569.(b) Arrowsmith M, Hill MS, Kociok-Köhn G. Chem. Eur. J. 2013; 19:2776-2783. [PubMed: 23307492] (c) Arrowsmith M, Hill MS, Hadlington T, Kociok-Köhn G, Weetman C. Organometallics. 2011; 30:5556-5559.

9. (a) Dureen MA, Stephan DW. J. Am. Chem. Soc. 2010; 132:13559-13568. [PubMed: 20809578] (b) R Cabrera A, S Rojas R, Valderrama M, Plüss P, Berke H, G Daniliuc C, Kehr G, Erker G. Dalton Trans. 2015; 44:19606-19614. [PubMed: 26202830] (c) Theuergarten E, Schlösser J, Schlüns D, Freytag M, G Daniliuc C, G Jones P, Tamm M. Dalton Trans. 2012; 41:9101-9110. [PubMed: 22588317]

10. (a) Gellrich U, Diskin-Posner Y, Shimon LJW, Milstein D. J. Am. Chem. Soc. 2016; 138:1330713313. [PubMed: 27629234] (b) Appelt C, Westenberg H, Bertini F, Ehlers AW, Slootweg JC, Lammertsma K, Uhl W. Angew. Chem. Int. Ed. 2011; 50(17):3925-3928.

11. (a) Li J, Li B, Liu R, Jiang L, Zhu H, Roesky HW, Dutta S, Koley D, Liu W, Ye Q. Chem. Eur. J. 2016; 22:14499-14503. [PubMed: 27538519] (b) Yu Y, Li J, Liu W, Ye Q, Zhu H. Dalton Trans. 2016; 45:6259-6268. [PubMed: 26658532] (c) Freitag S, Henning J, Schubert H, Wesemann L. Angew. Chem. Int. Ed. 2013; 52:5640-5643.

12. (a) Xiong Y, Yao S, Driess M. Organometallics. 2009; 28:1927-1933.(b) Gau D, Rodriguez R, Kato T, Saffon-Merceron N, de Cózar A, Cossío FP, Baceiredo A. Angew. Chem. Int. Ed. 2011; 50:1092-1096.(c) Delawar M, Gehrhus B, B Hitchcock P. Dalton Transactions. 2005; 0(17):29452953.

13. Nifantiev EE, Grachev MK, Burmistrov SY. Chem. Rev. 2000; 100:3755-3800. [PubMed: 11749327]

14. Power PP. Nature. 2010; 463:171-177. [PubMed: 20075912]

15. Myers TW, Berben LA. J. Am. Chem. Soc. 2013; 135:9988-9990. [PubMed: 23799284]

16. W Myers T, A Berben L. Chem. Sci. 2014; 5(7):2771-2777. 
17. Zhao W, McCarthy SM, Lai TY, Yennawar HP, Radosevich AT. J. Am. Chem. Soc. 2014; 136(50): 17634-17644. [PubMed: 25401723]

18. Burck S, Gudat D, Nieger M, Du Mont W-W. J. Am. Chem. Soc. 2006; 128:3946-3955. [PubMed: 16551102]

19. (a) Chong CC, Hirao H, Kinjo R. Angew. Chem. Int. Ed. 2014; 53:3342-3346.(b) Chong CC, Hirao H, Kinjo R. Angew. Chem. Int. Ed. 2015; 54:190-194.

20. Adams MR, Tien C-H, Huchenski BSN, Ferguson MJ, Speed AWH. Angew. Chem. Int. Ed. 2017; doi: 10.1002/anie.201611570

21. Gudat D. Acc. Chem. Res. 2010; 43:1307-1316. [PubMed: 20572668]

22. Snow SS, Jiang DX, Parry RW. Inorg. Chem. 1985; 24:1460-1463.

23. A unidentified trace impurity from the in situ preparation of 2 , whose concentration does not change with time, is also observed in ${ }^{31} \mathrm{P}$ NMR at $\delta 140.1 \mathrm{ppm}$.

24. (a) Keaton RJ, Blacquiere JM, Baker RT. J. Am. Chem. Soc. 2007; 129:1844-1845. [PubMed: 17253687] (b) Pun D, Lobkovsky E, J Chirik P. Chem. Commun. 2007; 0:3297-3299.(c) Chaplin AB, Weller AS. Angew. Chem. Int. Ed. 2010; 49:581-584.

25. (a) Stahl T, Müther K, Ohki Y, Tatsumi K, Oestreich M. J. Am. Chem. Soc. 2013; 135:1097810981. [PubMed: 23855894] (b) Anaby A, Butschke B, Ben-David Y, Shimon LJW, Leitus G, Feller M, Milstein D. Organometallics. 2014; 33:3716-3726.

26. (a) Wilczynski R, Sneddon LG. J. Am. Chem. Soc. 1980; 102:2857-2858.(b) Wilczynski R, Sneddon LG. Inorg. Chem. 1981; 20:3955-3962.(c) Wilczynski R, Sneddon LG. Inorg. Chem. 1982; 21:506-514.(d) Davan T, Corcoran EW, Sneddon LG. Organometallics. 1983; 2:1693-1694. (e) Pender MJ, Carroll PJ, Sneddon LG. J. Am. Chem. Soc. 2001; 123:12222-12231. [PubMed: 11734022] (f) Gridnev ID, Miyaura N, Suzuki A. Organometallics. 1993; 12:589-592.(g) Kaithal A, Chatterjee B, Gunanathan C. Org. Lett. 2015; 17:4790-4793. [PubMed: 26381014] (h) Burgess K, Jaspars M. Tetrahedron Lett. 1993; 34:6813-6816.(i) Burgess K, Jaspars M. Organometallics. 1993; 12:4197-4200.(j) Yamamoto Y, Fujikawa R, Umemoto T, Miyaura N. Tetrahedron. 2004; 60:10695-10700.(k) Satoh M, Nomoto Y, Miyaura N, Suzuki A. Tetrahedron Lett. 1989; 30:3789_ 3792.(l) Männig D, Nöth H. Angew. Chem. Int. Ed. Engl. 1985; 24:878-879.

27. (a) Frey GD, Masuda JD, Donnadieu B, Bertrand G. Angew. Chem. Int. Ed. 2010; 49:9444-9447. (b) Lastovickova DN, Bielawski CW. Organometallics. 2016; 35:706-712.

28. (a) Dureen MA, Lough A, Gilbert TM, Stephan DW. Chem. Commun. 2008:4303-4305.(b) Eisenberger P, Bailey AM, Crudden CM. J. Am. Chem. Soc. 2012; 134:17384-17387. [PubMed: 23030065]

29. Waterman R. Organometallics. 2013; 32:7249-7263.

30. Hill MS, Liptrot DJ, Weetman C. Chem. Soc. Rev. 2016; 45:972-988. [PubMed: 26797470]

31. (a) Corey EJ, Bakshi RK, Shibata S, Chen CP, Singh VK. J. Am. Chem. Soc. 1987; 109:79257926.(b) Corey EJ, Bakshi RK, Shibata S. J. Am. Chem. Soc. 1987; 109:5551-5553.(c) Corey EJ, Helal CJ. Angew. Chem. Int. Ed. 1998; 37:1986-2012.

32. Revunova K, Nikonov GI. Dalton Trans. 2014; 44:840-866.

33. Chong CC, Kinjo R. ACS Catal. 2015; 5:3238-3259.

34. (a) Greenhalgh R, Newbery JE, Woodcock R, Hudson RF. Chem. Commun. 1969:22.(b) Hudson RF, Brown C. Acc. Chem. Res. 1972; 5:204-211.

35. McCarthy SM, Lin Y-C, Devarajan D, Chang JW, Yennawar HP, Rioux RM, Ess DH, Radosevich AT. J. Am. Chem. Soc. 2014; 136:4640-4650. [PubMed: 24597970] 


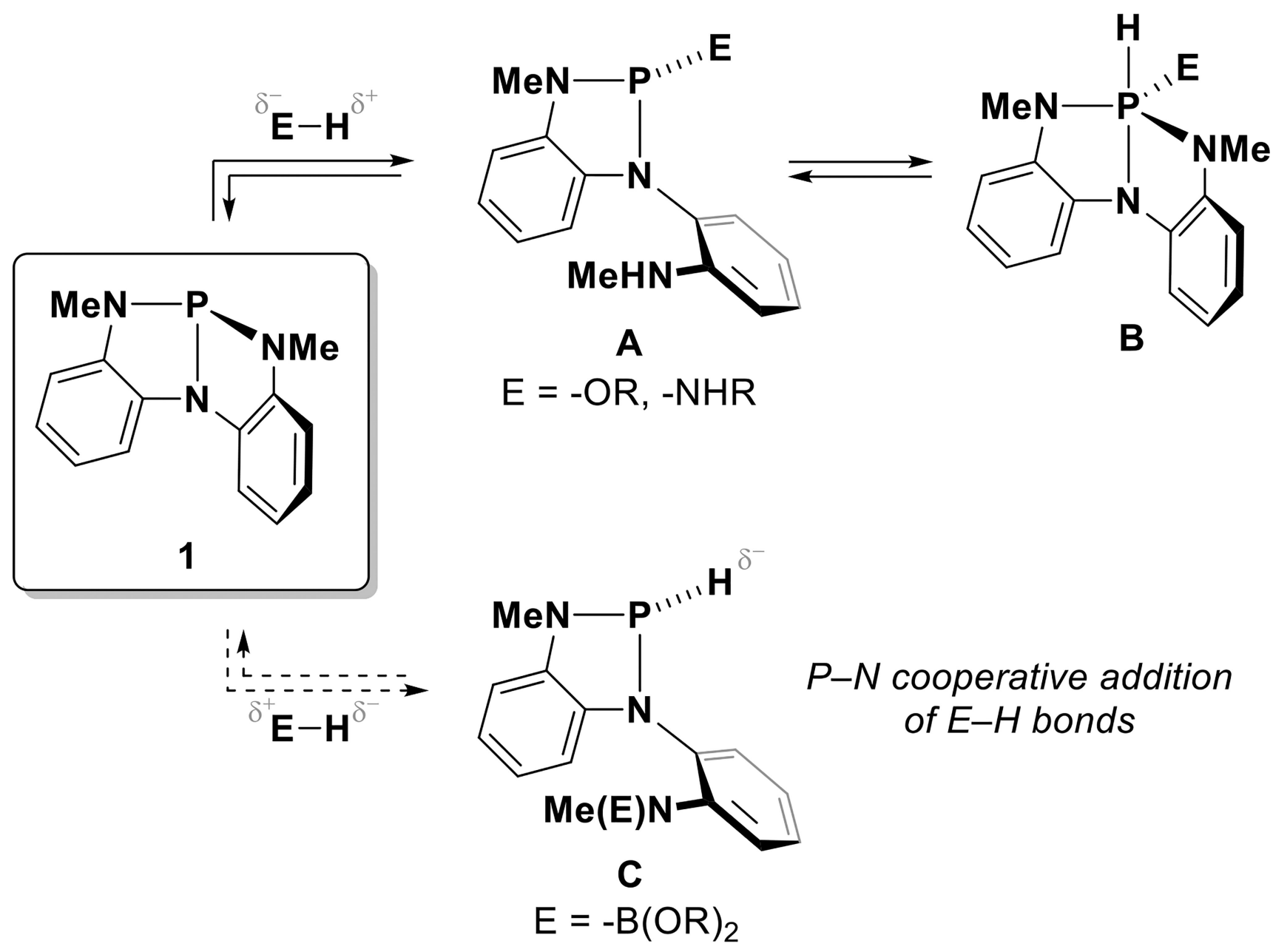

Figure 1.

Geometrically deformed phosphorous triamide 1 and its reactivity. (Top) Phosphorus-ligand cooperative addition of protic E-H substrates to 1, see ref. 17. (Bottom) Regioisomeric phosphorus-ligand cooperative addition of hydridic E-H to $\mathbf{1}$. 


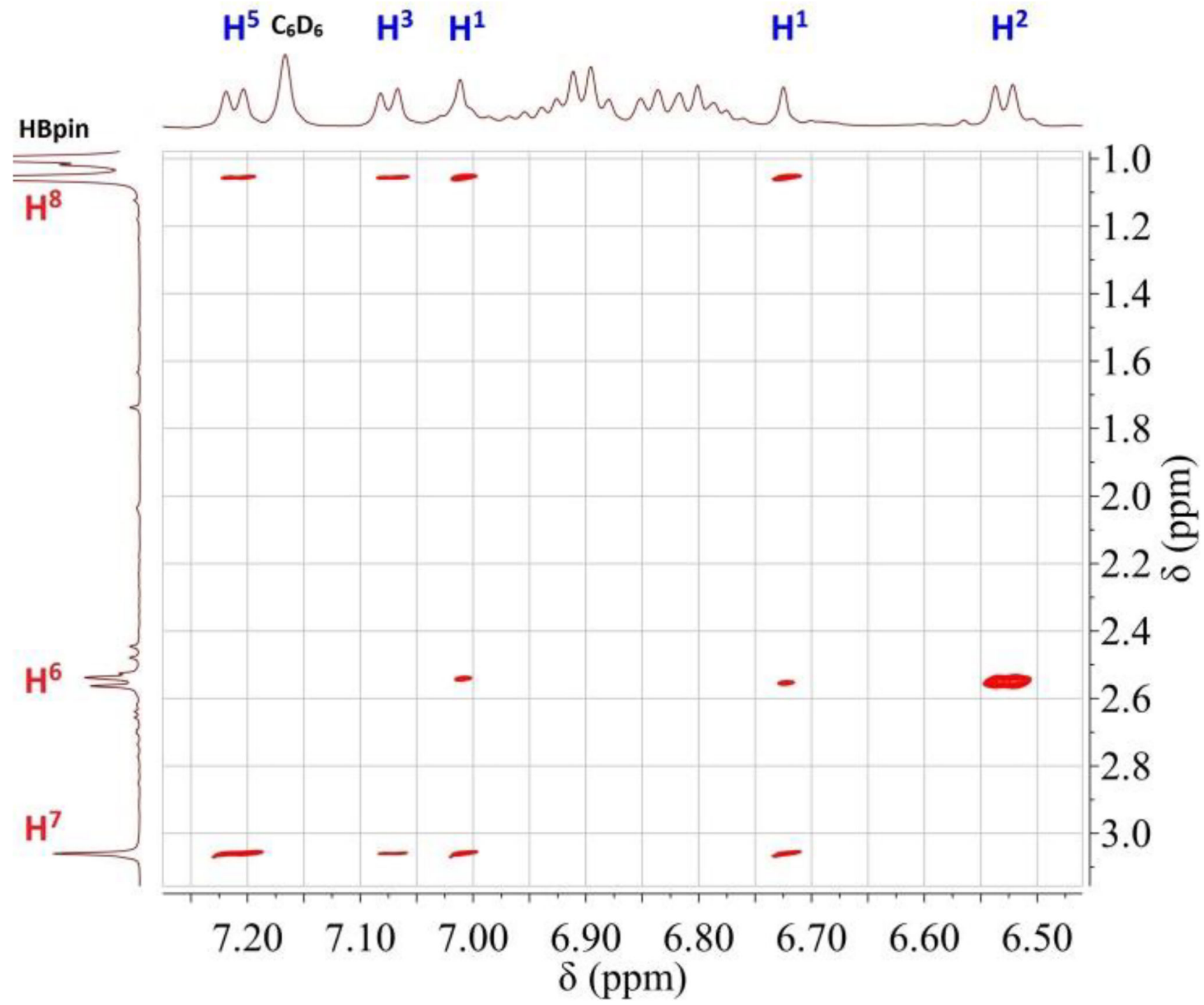

Figure 2.

Annotated partial two-dimensional ${ }^{1} \mathrm{H}-{ }^{1} \mathrm{H}$ NOESY spectrum of $\mathbf{2}$ showing correlations between protons that share dipolar coupling $\left(\mathrm{C}_{6} \mathrm{D}_{6}, 298 \mathrm{~K}, 500 \mathrm{MHz}\right)$. Hydrogen atom labels refer to numbering of 2 in Scheme 1. See SI for unabridged spectrum. 
(A)

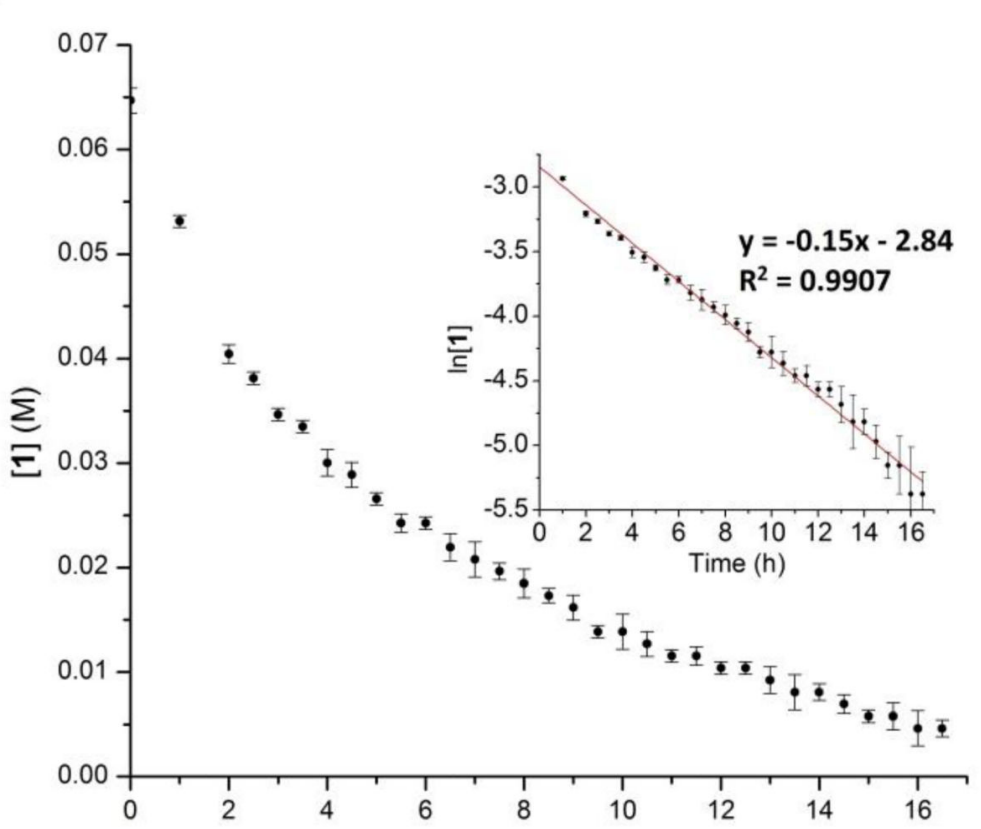

(B)

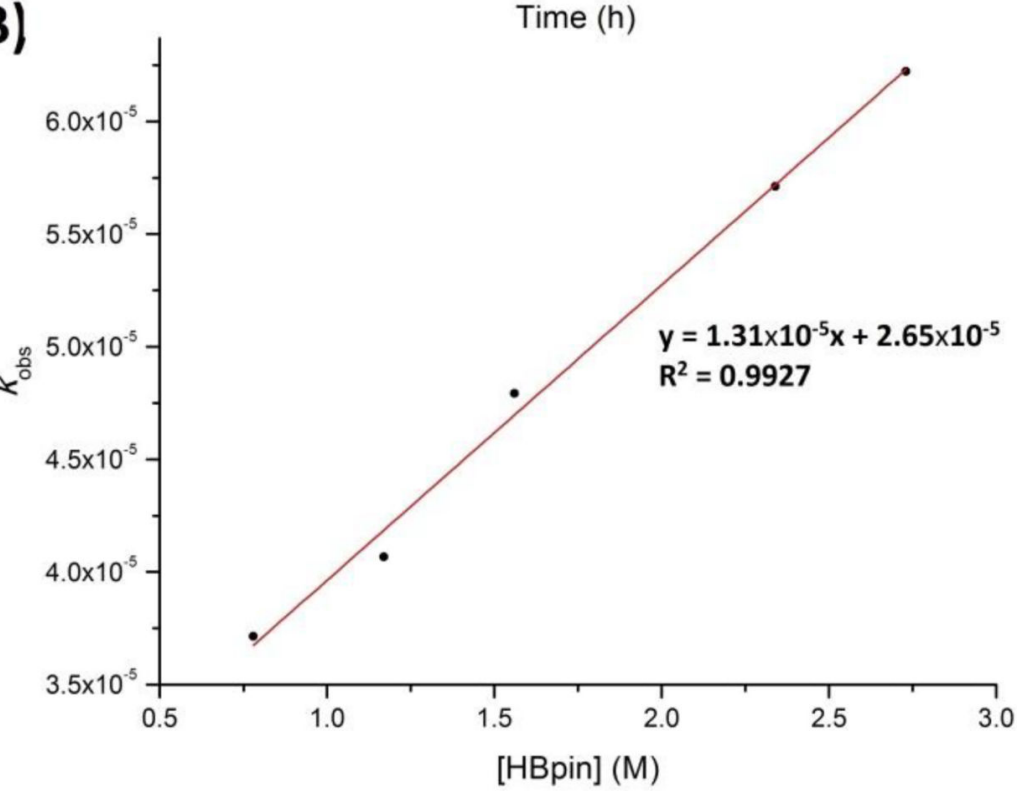

Figure 3.

Kinetics experiments of the cooperative HBpin activation with 1. (A) Plot of [1] vs time monitored $\left([\mathbf{1}]_{\mathrm{o}}=78 \mathrm{mM},[\mathrm{HBpin}]_{\mathrm{o}}=117 \mathrm{mM}, \mathrm{C}_{6} \mathrm{D}_{6}, 297 \mathrm{~K}\right)$. (Inset) Plot of ln [1] vs time with linear least-squares fit. (B) Plot of $k_{\mathrm{obs}}$ vs [HBpin $]_{0}$ with linear least-squares fit. 


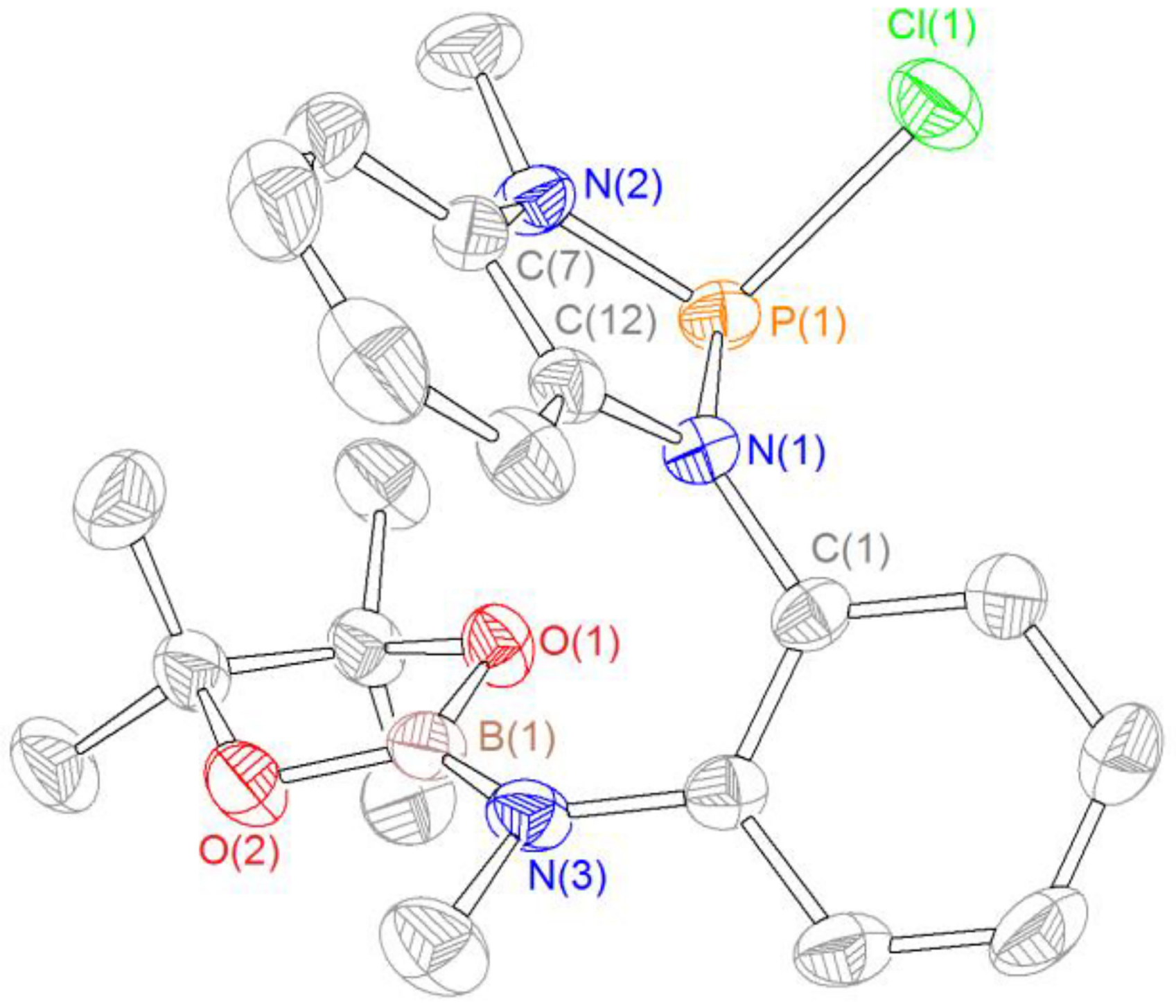

Figure 4.

Molecular structure of $\mathbf{3}$ with 50\% probability level rendered thermal ellipsoid plot. Selected bond lengths $[\AA]$ and angles $\left[{ }^{\circ}\right]$ : $\mathrm{P}(1)-\mathrm{Cl}(1)$ 2.276(1), $\mathrm{P}(1)-\mathrm{N}(1)$ 1.681(2), $\mathrm{P}(1)-\mathrm{N}(2)$ 1.665(2), $\mathrm{N}(3)-\mathrm{B}(1)$ 1.418(4), $\mathrm{O}(1)-\mathrm{B}(1)$ 1.377(4), $\mathrm{O}(2)-\mathrm{B}(1)$ 1.371(3), $\mathrm{N}(1)-\mathrm{C}(12)$ 1.401(4), N(2)-C(7) 1.400(7), N(1)-C(1) 1.428(3), N(2)-C(13) 1.459(4); N(1)-P(1)-Cl(1) 103.20(8), N(2)-P(1)-Cl(1) 98.64(9), N(1)-P(1)-N(2) 90.40(1). 


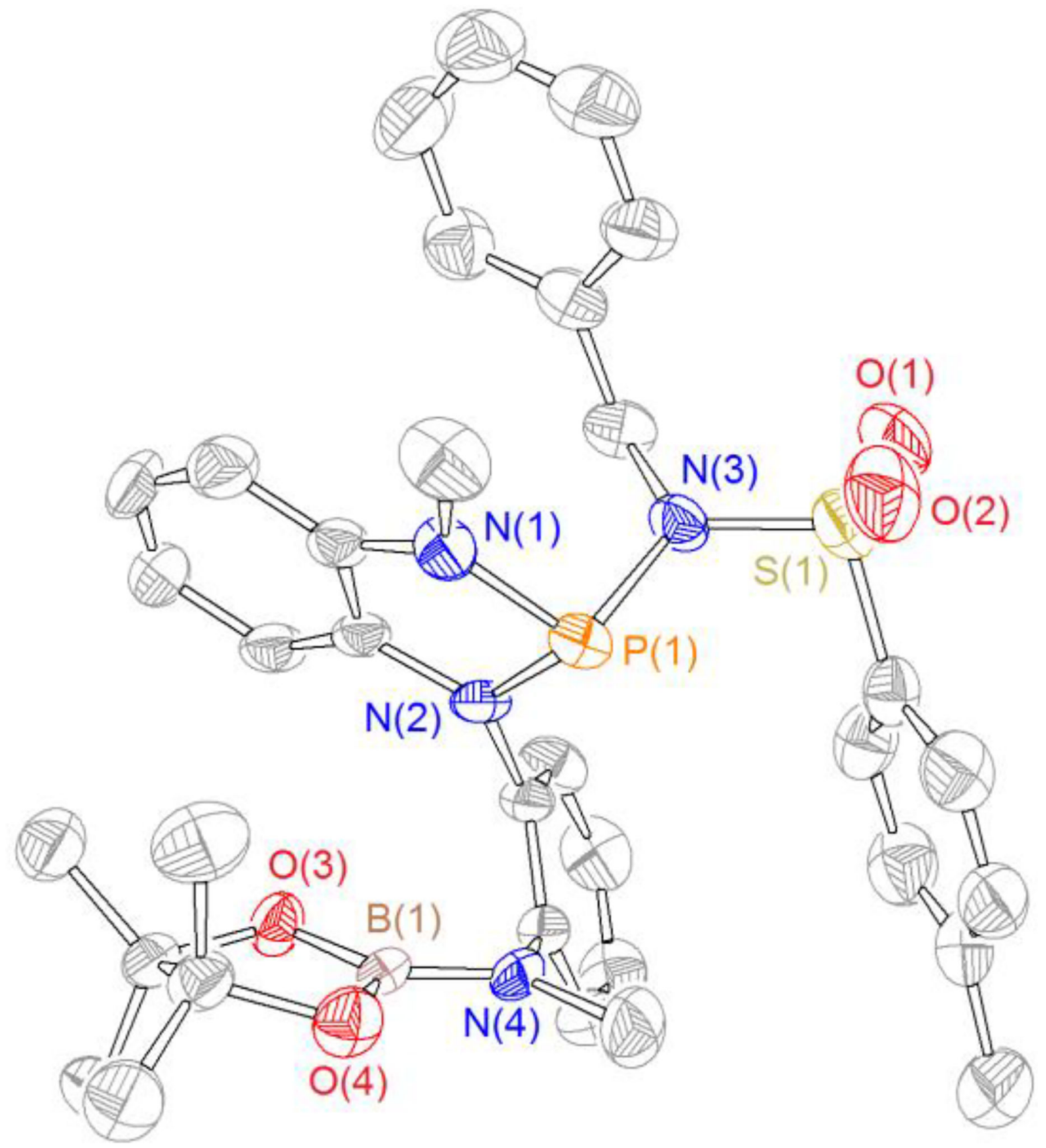

Figure 5.

Molecular structure of $\mathbf{4}$. The unit cell contains two crystallographically independent molecules, only one is shown for clarity. Thermal ellipsoid plot rendered at the $50 \%$ probability level. Selected bond lengths $[\AA]$ and angles $\left[{ }^{\circ}\right]$ : $\mathrm{P}(1)-\mathrm{N}(1) 1.712(4), \mathrm{P}(1)-\mathrm{N}(2)$ 1.681(4), P(1)-N(3) 1.770(4), N(3)-S(1) 1.652(5), N(1)-C(2) 1.388(7), N(2)-C(7) 1.390(7), $\mathrm{N}(2)-\mathrm{C}(8)$ 1.439(6), N(1)-C(1) 1.469(6); N(1)-P(1)-N(3) 103.7(2), N(2)-P(1)-N(3) 101.4(2), $\mathrm{N}(2)-\mathrm{P}(1)-\mathrm{N}(1) 88.2(2)$. 
(A)

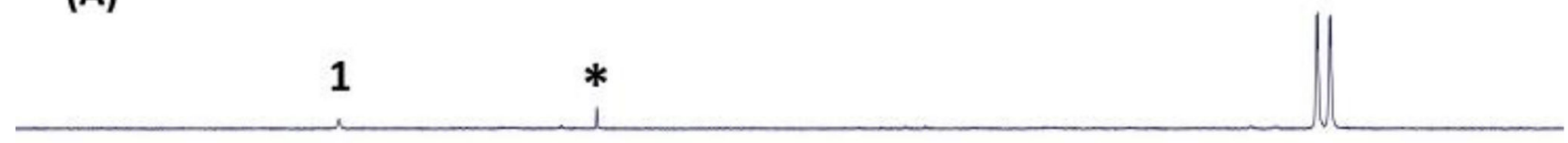

(B)

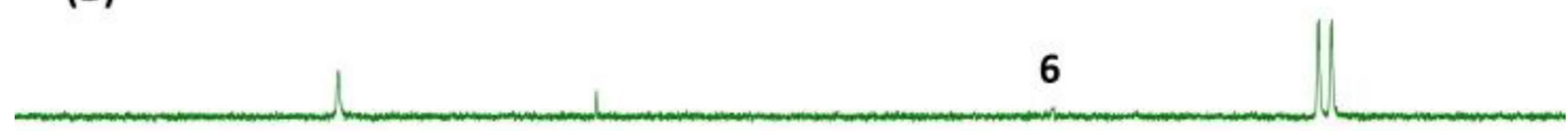

(C)

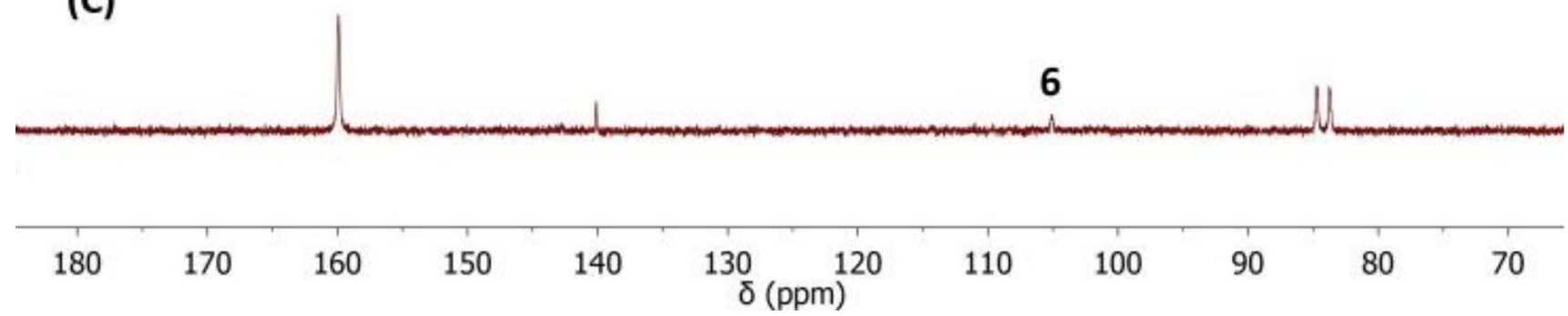

Figure 6.

Representative time-stacked ${ }^{31} \mathrm{P}$ NMR spectra $\left(\mathrm{C}_{6} \mathrm{D}_{6}, 145.79 \mathrm{MHz}, 25{ }^{\circ} \mathrm{C}\right)$ for the reaction of $\mathbf{2}(\delta 84.2 \mathrm{ppm})$ with imine 5 to give $\mathbf{1}(\delta 159.9 \mathrm{ppm})$ via $\mathbf{6}(\delta 105.1 \mathrm{ppm})$ at time points: (A) $10 \mathrm{~min}$, (B) $30 \mathrm{~min}$, (C) $12 \mathrm{~h}$. Asterisk marks unidentified by-product ( $\delta 140 \mathrm{ppm}$ ). 


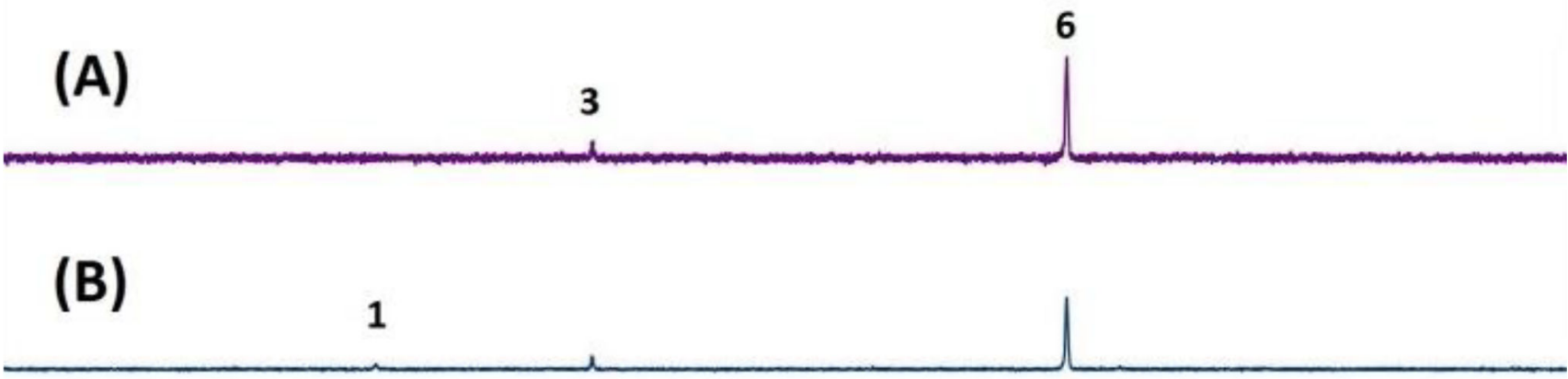

\section{(c)}

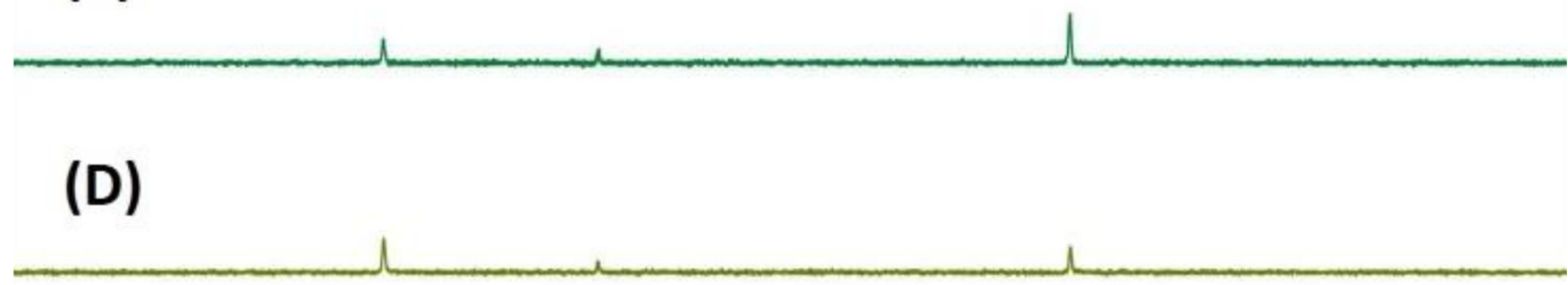

(E)

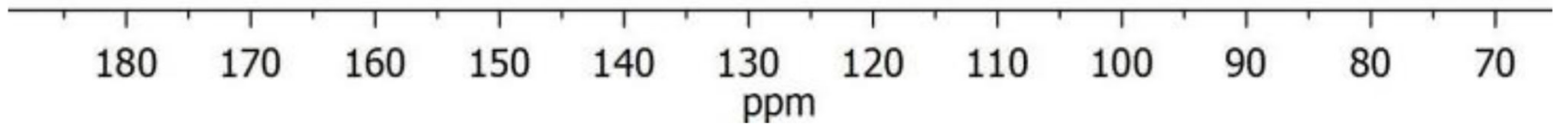

Figure 7.

Time-stacked ${ }^{31} \mathrm{P}$ NMR spectra $\left(\mathrm{C}_{6} \mathrm{D}_{6}, 145.79 \mathrm{MHz}, 25{ }^{\circ} \mathrm{C}\right)$ for the conversion of $\mathbf{6}$ to $\mathbf{1}$ at time points (A) $10 \mathrm{~min}$, (B) $3 \mathrm{~h}$, (C) $12 \mathrm{~h}$, (D) $36 \mathrm{~h}$, (E) $60 \mathrm{~h}$. 


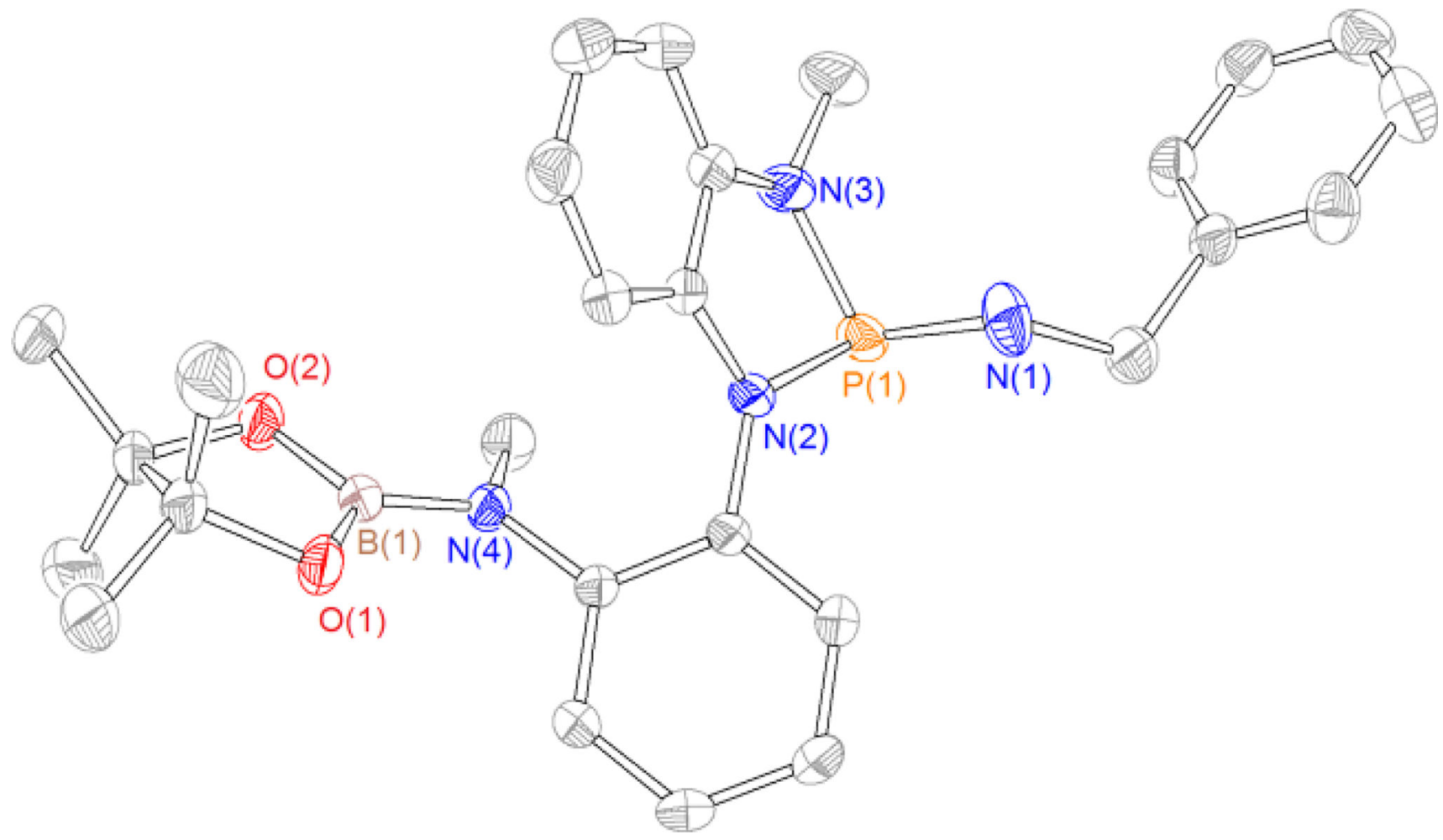

Figure 8.

Molecular structure of $\mathbf{8}$. Thermal ellipsoid plot rendered at the 50\% probability level.

Selected bond lengths $[\AA ̊]$ and angles [ $\left[^{\circ}\right]$ : $\mathrm{P}(1)-\mathrm{N}(1)$ 1.664(2), $\mathrm{P}(1)-\mathrm{N}(2) 1.732(2), \mathrm{P}(1)-\mathrm{N}(3)$

$1.716(2), \mathrm{N}(2)-\mathrm{C}(8) 1.408(2), \mathrm{N}(2)-\mathrm{C}(14) 1.417(2), \mathrm{N}(3)-\mathrm{C}(13) 1.392(3), \mathrm{N}(3)-\mathrm{C}(20)$

1.452(3); N(1)-P(1)-N(2) 105.36(9), N(1)-P(1)-N(3) 105.25(9), N(2)-P(1)-N(3) 87.57(8). 


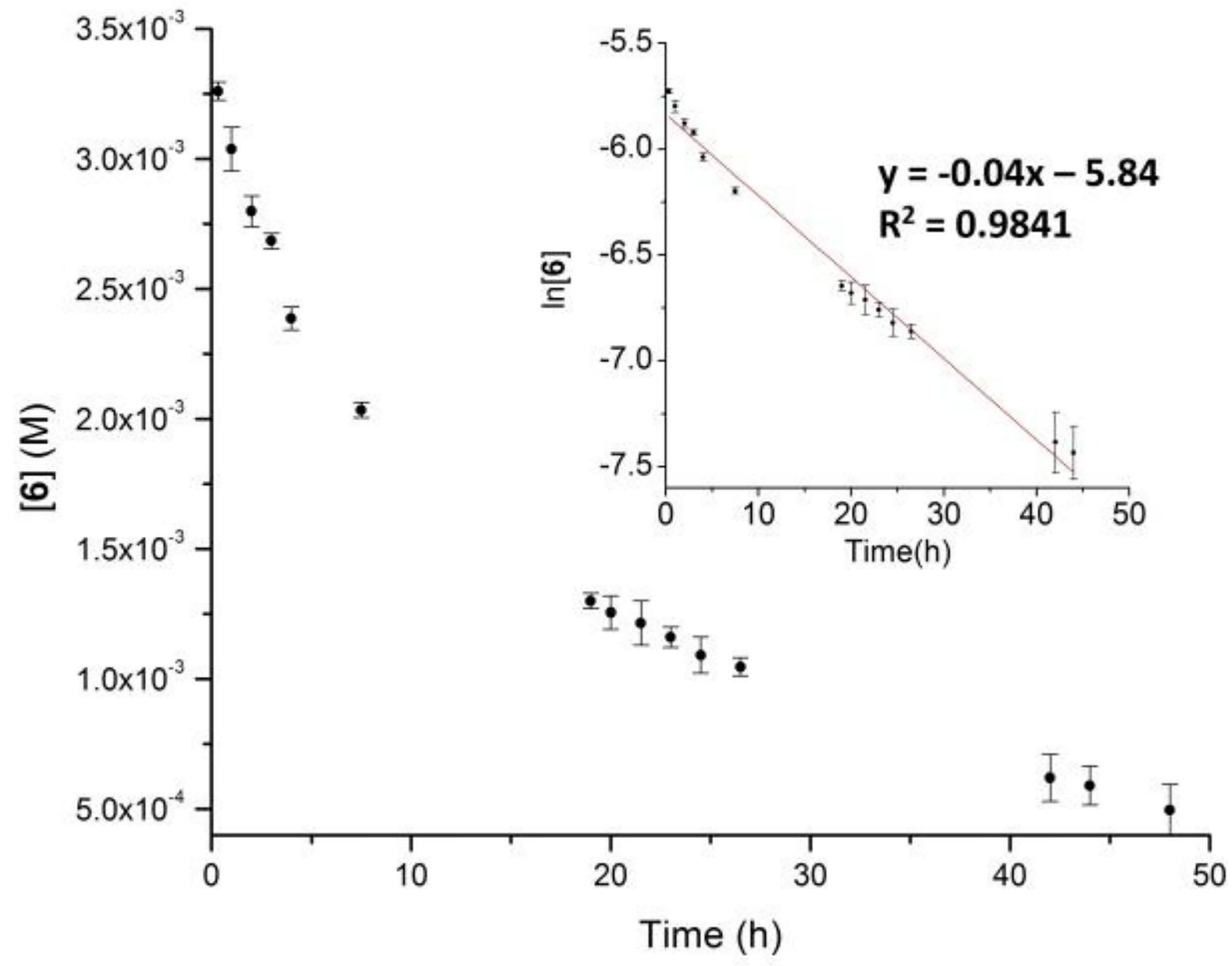

Figure 9.

Kinetics experiments of the cooperative B-N elimination from 6. (Main) Plot of [6] vs time monitored $\left([6]_{\mathrm{o}}=3.3 \mathrm{mM}, \mathrm{C}_{6} \mathrm{D}_{6}, 297 \mathrm{~K}\right)$. (Inset) Plot of $\ln [\mathbf{6}]$ vs time with linear leastsquares fit. 


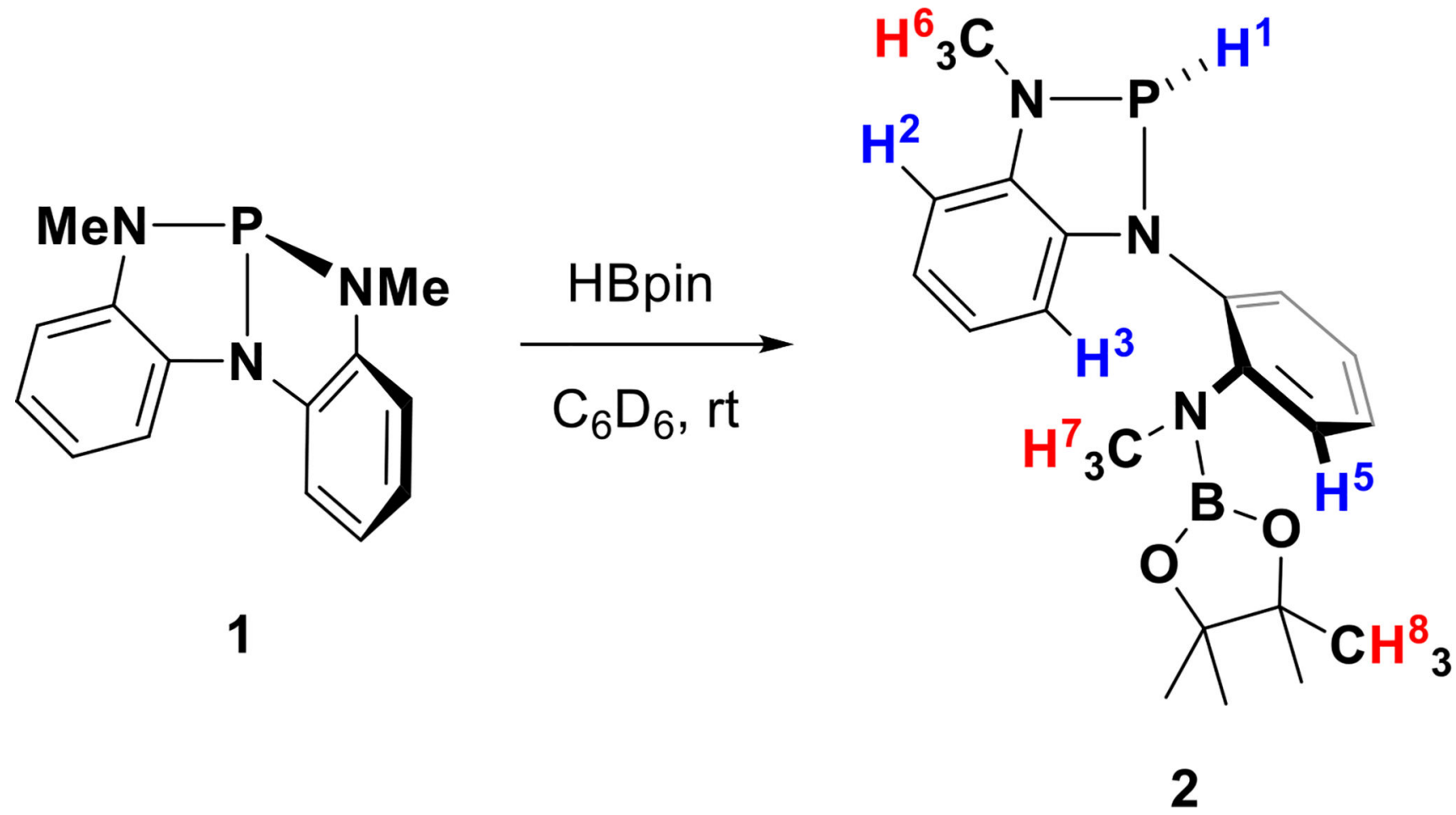

Scheme 1.

Activation of pinacolborane with $\mathbf{1}$ and resulting $P$-hydrido-1,3,2-diazaphospholene 2 . 

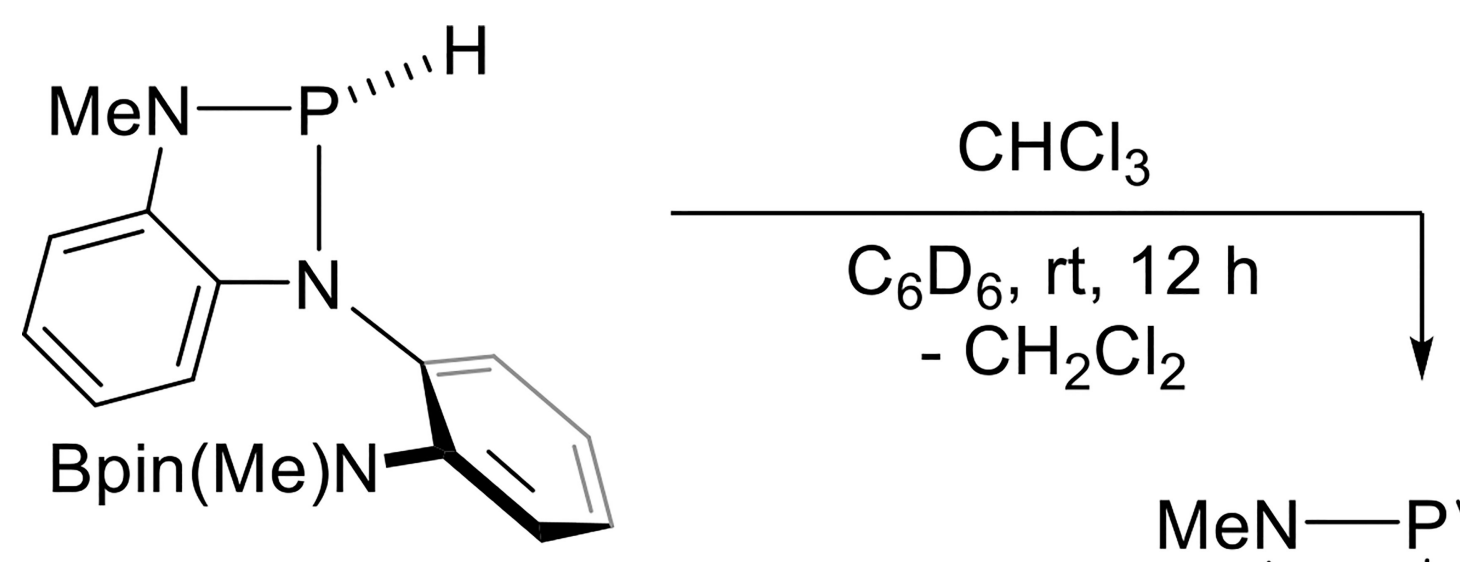

2
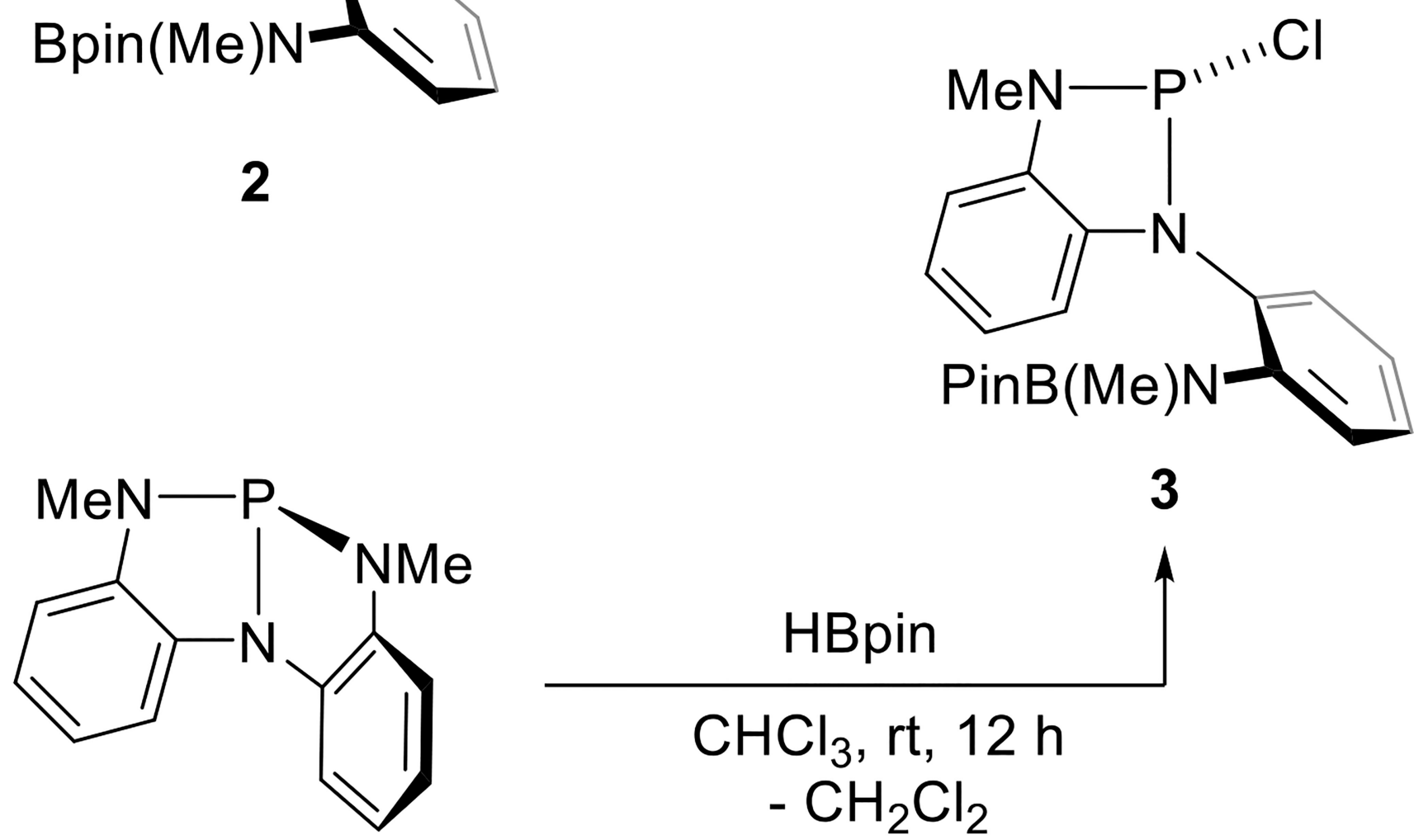

1

HBpin

$\mathrm{CHCl}_{3}, \mathrm{rt}, 12 \mathrm{~h}$

- $\mathrm{CH}_{2} \mathrm{Cl}_{2}$

Scheme 2.

Hydrodechlorination of chloroform by $\mathbf{2}$ and fomation of $\mathbf{3}$. 


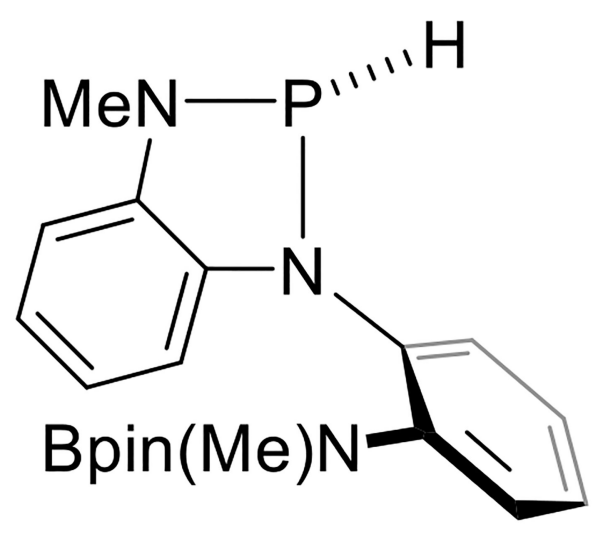

2

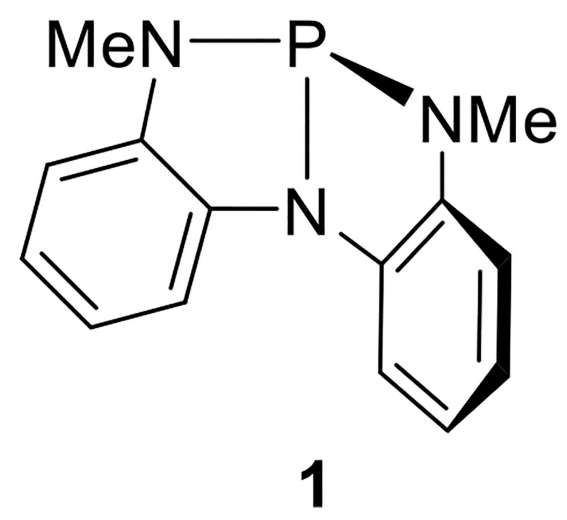

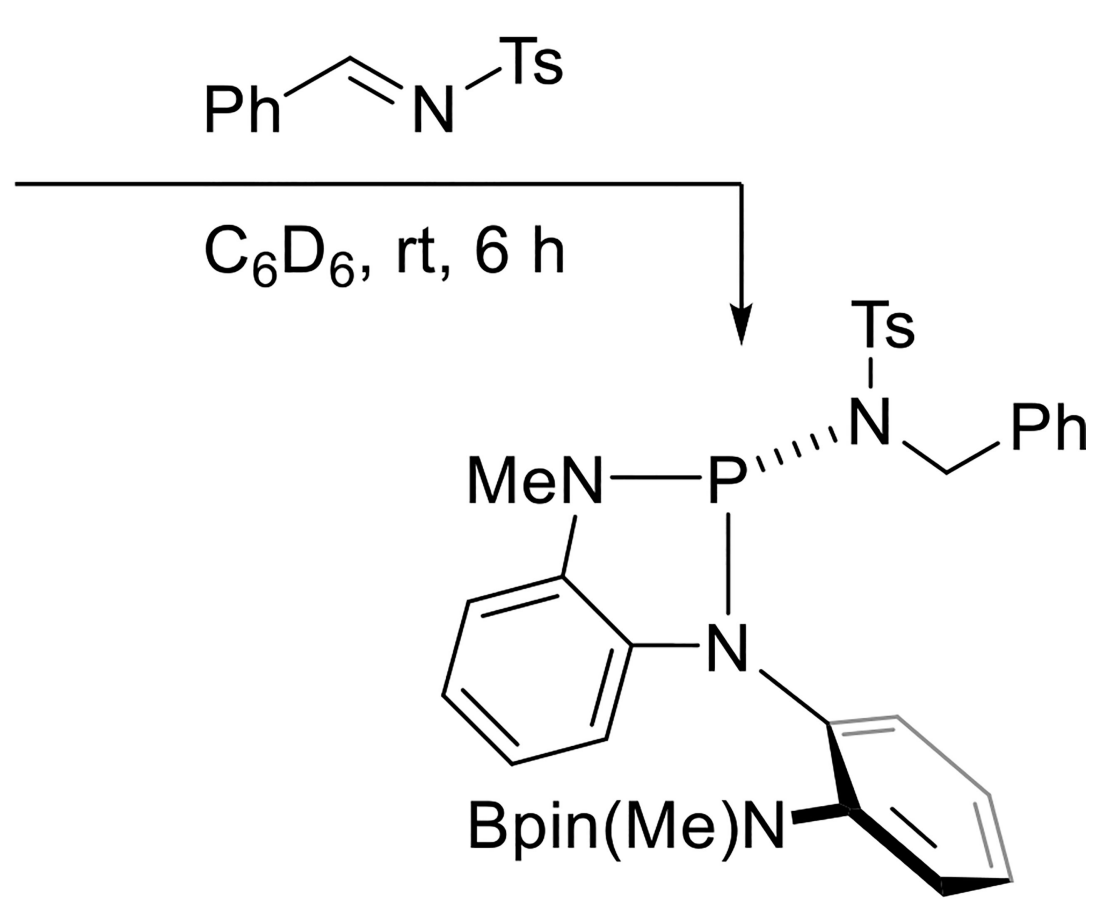

4

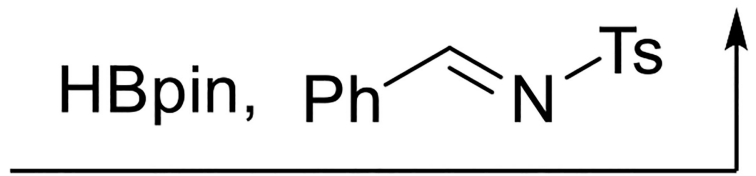

$\mathrm{C}_{6} \mathrm{D}_{6}, \mathrm{rt}, 12 \mathrm{~h}$

Scheme 3.

Reduction of $N$-tosyl-1-phenylmethanimine and formation of the triazaphospholene 4. 


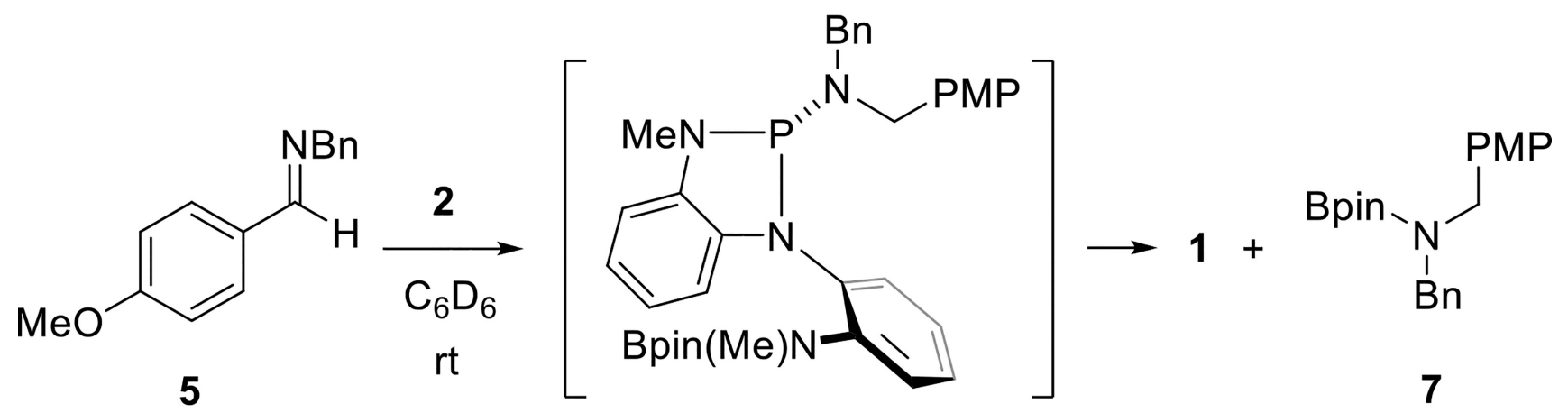

6

Scheme 4.

Reaction of $\mathbf{2}$ with imine $\mathbf{5}$ and the resulting regeneration of $\mathbf{1}$ via intermediate $\mathbf{6}$. PMP $=p$ methoxyphenyl. 


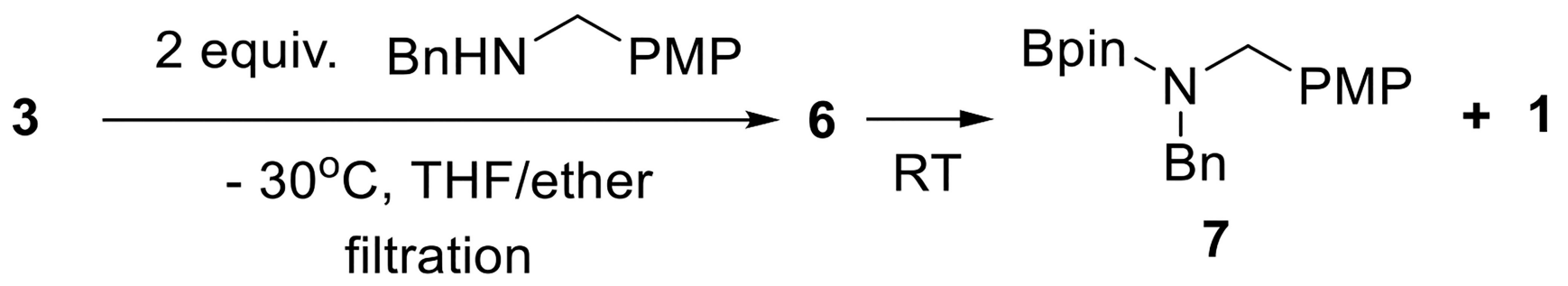

Scheme 5.

The independent synthesis of $\mathbf{6}$ and subsequent elimination of the $N$-borylamine 7. PMP=pmethoxyphenyl. 


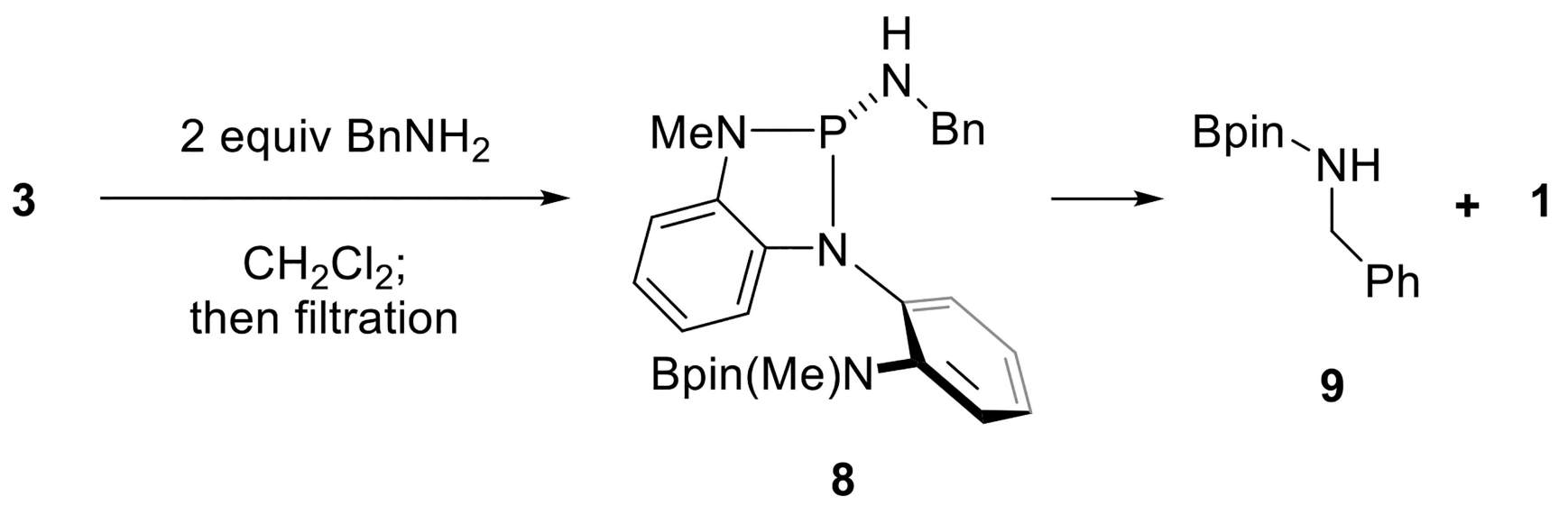

Scheme 6.

Synthesis of $\mathbf{8}$ and its conversion to $\mathbf{1}$. 

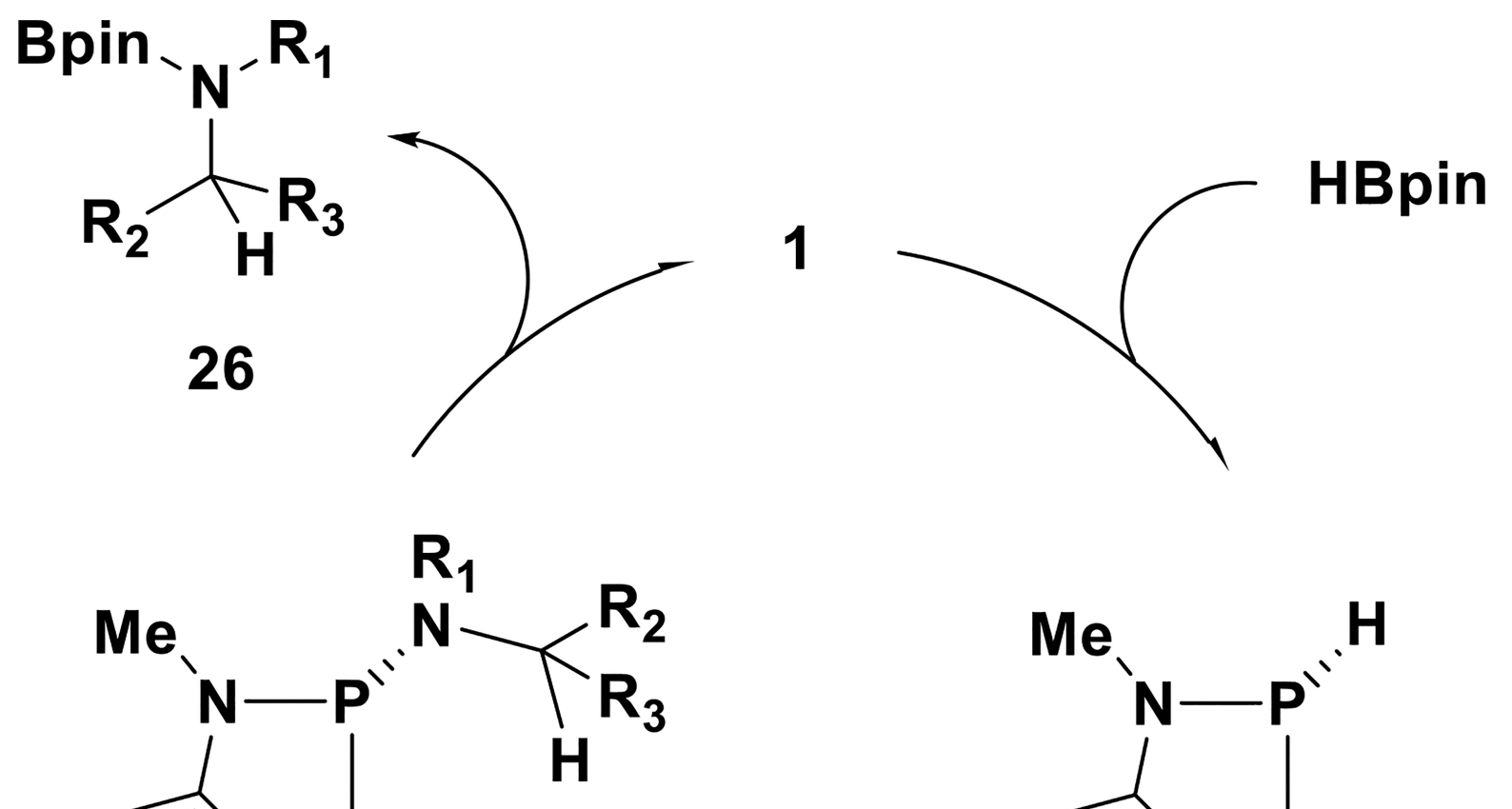

25
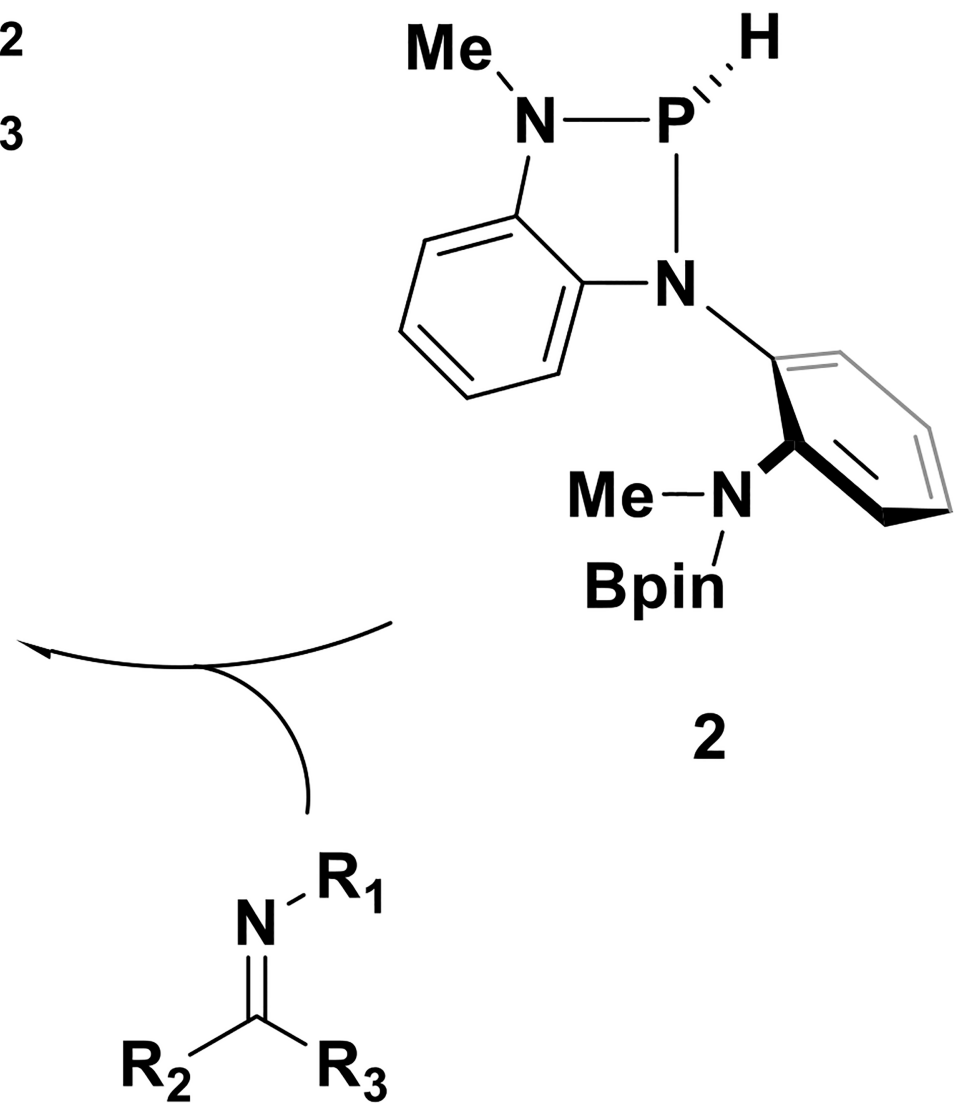

2

Scheme 7.

Proposed phosphorus-ligand cooperative mechanism for the catalytic imine hydroboration. 